\title{
Environmental governance theories: a review and application to coastal systems
}

\author{
$\underline{\text { Stefan Partelow }}^{1}$, Achim Schlüter $^{1,2}$, Derek Armitage ${ }^{3}$, Maarten Bavinck ${ }^{4,5}$, Keith Carlisle $^{6}$, Rebecca L. Gruby ${ }^{6}$, Anna-Katharina

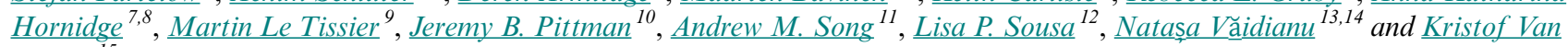 \\ Assche $^{15}$
}

\begin{abstract}
This article synthesizes and compares environmental governance theories. For each theory we outline its main tenets, claims, origin, and supporting literature. We then group the theories into focused versus combinatory frameworks for comparison. The analysis resonates with many types of ecosystems; however, to make it more tangible, we focus on coastal systems. First, we characterize coastal governance challenges and then later link salient research questions arising from these challenges to the theories that may be useful in answering them. Our discussion emphasizes the usefulness of having a diverse theoretical toolbox, and we argue that if governance analysts are more broadly informed about the theories available, they may more easily engage in open-minded interdisciplinary collaboration. The eight theories examined are the following: polycentricity, network governance, multilevel governance, collective action, governmentality (power / knowledge), adaptive governance, interactive governance theory (IGT), and evolutionary governance theory (EGT). Polycentricity and network governance both help examine the links or connections in governance processes. Polycentricity emphasizes structural configurations at a broader level, and network governance highlights agency and information flow within and between individuals or organizations. Collective action theory is helpful for examining community level governance, and helps analyze variables hindering or enabling self-organization and shared resource outcomes. In contrast, multilevel governance helps understand governance integration processes between localities, regions, and states across administrative, policy, or legal dimensions. Governmentality is helpful for understanding the role of discourse, power, knowledge, and narratives in governance, such as who creates them and who becomes governed by them with what effect. Adaptive governance helps analyze the links between context, change, and resilience. IGT helps examine the interdependencies between the systems being governed and the governing systems. EGT is helpful for unpacking how coevolutionary processes shape governance and the options for change.
\end{abstract}

Key Words: collaborative governance; comanagement; land-sea; marine; natural resource governance; natural resource management; transdisciplinarity; watershed; wetland

\section{INTRODUCTION}

Environmental and natural resource governance scholarship dates back to the 1950s (Davidson and Frickel 2004). Such scholarship has generally aimed to understand how different governance processes or policies influence desired outcomes such as preservation, conservation, livelihoods, and sustainable use or development. However, environmental governance scholarship lacks cohesion and relational orientation. Many concepts (Davidson and Frickel 2004), governance theories (Ansell and Torfing 2016, Cox et al. 2016), and frameworks (Binder et al. 2013, Pulver et al. 2018, Nunan 2019) exist, but in practice their proponents struggle to satisfactorily explain or predict the occurrence of undesirable outcomes.

However, there are also many examples of governance success as analyzed by focused theories, providing some with robust empirical support. More recently, there has been a rise in more combinatory analytical theories and frameworks, reflecting scholarship on social-ecological systems (Cox et al. 2016, Partelow 2018, Colding and Barthel 2019), but also assuming multiple ways of knowing, combining, and building on foundational theory (Bennett and Satterfield 2018). Much of the combinatory analyses in environmental governance are linked to concepts that bridge scholarship between the social and natural sciences, while adding a complex systems-thinking approach and a normative orientation. This is evident in concepts such as resilience, ecosystem services, social-ecological systems, and sustainability. Although the bridging of theories is usually taken as a positive trend, a critical reflection thereof is rare, leading to uncertainty in both theoretical and practical governance understandings. A synthetic overview and analysis that identifies core claims and abilities of various environmental governance theories, therefore, remains a substantial gap for orienting the diverse contributions of each.

We aim to address this gap with a concise appraisal of the environmental and natural resource governance literature. Our theory selection and analysis rely in part on an expert author consortium, and we aim to provide an audit of where this literature stands and which directions point forward. Although

${ }^{1}$ Leibniz Centre for Tropical Marine Research (ZMT), Bremen, Germany, ${ }^{2}$ Jacobs University, Bremen, Germany, ${ }^{3}$ School of Environment, Resources and Sustainability, University of Waterloo, Canada, ${ }^{4}$ Amsterdam Institute for Social Science Research, University of Amsterdam, The Netherlands, ${ }^{5}$ UiT Arctic University of Norway, ${ }^{6}$ Human Dimensions of Natural Resources, Colorado State University, Fort Collins, CO, USA, ${ }^{7}$ German Development Institute / Deutsches Institut für Entwicklungspolitik (DIE), Germany, ${ }^{8}$ University of Bonn, Germany, ${ }^{9}$ MaREI, the SFI Research Centre for Energy, Climate and Marine, Environmental Research Institute, University College Cork, Ireland, ${ }^{10}$ Faculty of Environment, University of Waterloo, Canada, ${ }^{11}$ Faculty of Arts and Social Sciences, University of Technology Sydney, Australia, ${ }^{12}$ Centre for Environmental and Marine Studies (CESAM), Department of Environment and Planning, University of Aveiro, Portugal, ${ }^{13}$ Faculty of Natural Sciences and Agricultural Sciences, Ovidius University of Constanta, Romania, ${ }^{14}$ Interdisciplinary Center for Advanced Research on Territorial Dynamics, University of Bucharest, Romania, ${ }^{15}$ Department of Earth \& Atmospheric Science, University of Alberta, Canada 
Fig. 1. Diverse coastal systems and uses. (A) A large wetland and river on the coast of The Gambia. (B) A coastal beach populated by tourists in Turkey. (C) Large port development for tourism in the Caribbean. (D) Port development for industry and trade in Japan. (E) Wetland pond aquaculture system in an Indonesian mangrove forest with water supplied by tidal flows. (F) Small-scale fishing boats off the coast of Peru. (G) A Senegalese fishing village. (H) Offshore wind energy in the United States. Photos A, B, C, $\mathrm{D}, \mathrm{H}$ received from https://unsplash.com/. Photos E, F, G taken by the authors.
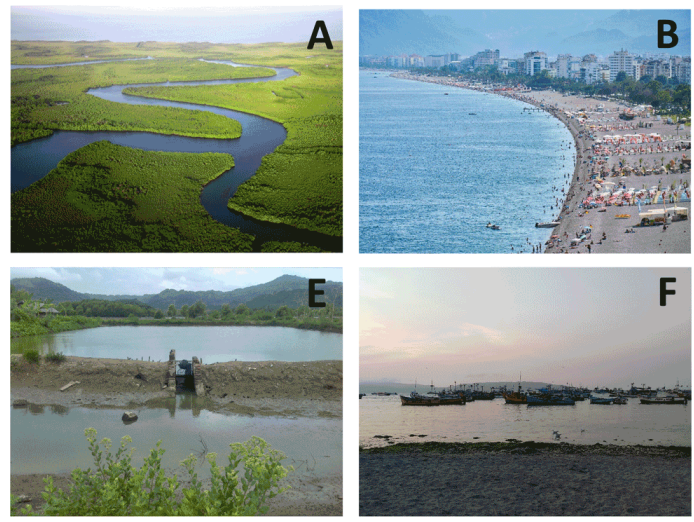
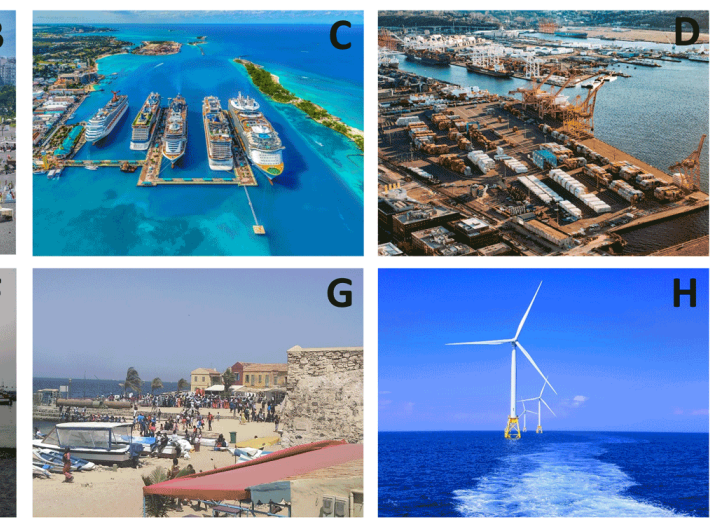

environmental governance is a diverse body of scholarship, the theories reviewed are applicable across sectors and thematic areas. To focus our synthesis empirically, and to provide a coherent set of examples to relationally orient each theory, we concentrate on coastal systems as a representative field with limited integration of governance activities and perspectives across a diversity of stakeholders, sectors, and land-sea interactions, while also being among the most impacted and exploited natural resource systems worldwide (Olsen 2003, Lebel 2012, Van Assche et al. 2020a). The coastal context outlined below provides us with a set of empirical examples with which to compare the analytical capabilities and applicability of each theory. However, the theories summarized are not limited to coastal application. We believe this article can be useful for any environmental governance scholar navigating the literature and seeking a synthetic overview with questions about the analytical usefulness of each theory and the relationships between theories.

\section{Governance of the coast}

The world's coastal zones represent some of the most diverse and productive ecological and social systems (United Nations 2016, UNESCO-IOC 2017). This raises challenges for analyzing and implementing coastal governance at various societal levels and scales (Glaser and Glaeser 2014). Coasts share characteristics of both land and sea systems; they make up dynamic interfaces combining features of both land- and seascapes (Fig. 1). However, coasts have dynamic and transboundary materiality, as well as high social, economic, and institutional diversity (Lebel 2012, Steinberg 2013, Schlüter et al. 2019). Multiple actors representing diverse interests and sectors engage with the coastal zone (e.g., tourism, shipping, offshore energy, residential development, recreation, conservation, resource extraction), thereby characterizing it as an overlapping and contested multiuse space. However, much of the focus on coastal zones for governing purposes is concentrated on the land-sea interface extending only a few kilometers inland and offshore, if not directly on the shore itself (Pittman and Armitage 2016, Van Assche et al. 2020a). A major challenge is that land and sea have also been historically regulated separately (Pittman and Armitage 2016, Schlüter et al. 2019), or they have been governed according to terrestrial models, which may be ill-suited to the fluidity and overlapping uses represented in coastal zones (Steinberg 2013).

Coasts now feature as priority research areas in national and global agendas, including economic development espoused by the UN 2030 Agenda (United Nations 2010, Visbeck 2018) and the UN Decade of Ocean Science for Sustainable Development (https://www.oceandecade.org/). Sustainable Development Goal (SDG) 14 showcases "Life Below Water" along with recognition that the sea has interdependencies with the achievement and implementation of nearly all other SDGs (Le Blanc et al. 2017, Ntona and Morgera 2018), many of which are interfaced through the coast. The Global Ocean Science Report (UNESCO-IOC 2017) outlines the integral role marine and coastal spaces play in global development, highlighting that over 3 billion people depend on marine and coastal biodiversity for their livelihood, and marine and coastal resources comprise $5 \%$ of global Gross Domestic Product (GDP). "Blue growth" agendas advanced by the European Commission and the United Nations Food and Agriculture Organization (FAO), as well as the World Bank (World Bank 2020) complement the ambitions of a "blue economy" or a marine oriented "bioeconomy" (Spalding 2016). These are advancing research, policy, development, and funding discourses worldwide. In fact, more than half of the world's population lives within $60 \mathrm{~km}$ of the sea, and three-quarters of all large cities are located there (UNEP 2020).

Coastal governance literature has largely drawn on conventional natural resource governance theories and their application to specific coastal contexts, nations, or regions (Gelcich et al. 2010, Fletcher et al. 2014, Freire-Gibb et al. 2014, Vince 2014), or on specific sectoral fields like fisheries (Jentoft and Chuenpagdee 2009, Bavinck et al. 2013), shipping (Seebens et al. 2013), smallislands (Glaser et al. 2018), offshore energy (Wright 2015), mining 
Fig. 2. Characterizing the unique diversity of coastal systems. Modified from Schlüter et al. (2019). Based on the social-ecological systems framework (McGinnis and Ostrom 2014). The figure conceptualizes the unique spectrum of variables on the coast, and the potential challenges for developing institutions to govern them, including coastal resources, resource systems, actors, and governance systems. Although this heuristic conceptualization is reductionistic, and skewed toward the worldview of scholars linked to the social-ecological systems framework, we believe it is nonetheless valuable as a brainstorming exercise to consider the broad spectrum of contexts that environmental governance theories attempt to explain and are applied within.

\begin{tabular}{|c|c|c|c|c|c|c|c|}
\hline High & High & High & Volatile & Clear & Huge & Expensive & High \\
\hline $\begin{array}{l}\text { - Tourist } \\
\text { - Water } \\
\text { - Fish } \\
\text { - Sand } \\
\text { - Seagrass } \\
\text { - Mangroves }\end{array}$ & $\begin{array}{l}\text { - Sea weed } \\
\text { - Herbivores } \\
\text { - Carnivores } \\
\text { - Mangroves } \\
\text { - Fresh water } \\
\text { - Sand }\end{array}$ & $\begin{array}{l}\text { - Tourists } \\
\text { - Coastal view } \\
\text { - Special fish } \\
\text { - Common fish } \\
\text { - Mollusk } \\
\text { - Wind }\end{array}$ & $\begin{array}{l}\text { - Fresh water } \\
\text { - Tourists } \\
\text { - Certain fish } \\
\text { - Aquaculture } \\
\text { - Mangroves }\end{array}$ & $\begin{array}{l}\text { - } \text { Forest } \\
\text { - Catchment } \\
\text { - Soil nutrients } \\
\text { - Lobster } \\
\text { - Mangrove } \\
\text { - Nutrients }\end{array}$ & $\begin{array}{l}\text { - Catchment } \\
\text { - Turtle area } \\
\text { - Fishing area } \\
\text { - Estuary } \\
\text { - Coral Reef } \\
\text { - Beach }\end{array}$ & $\begin{array}{l}\text { - Ports } \\
\text { - Hotels } \\
\text { - Fishing fleet } \\
\text { - Cages } \\
\text { - Drag nets } \\
\text { - Hand-lines }\end{array}$ & $\begin{array}{l}\text { - Tourism } \\
\text { - Aquaculture } \\
\text { - Muscles } \\
\text { - Seagrass } \\
\text { - Coral Reef } \\
\text { - Corals }\end{array}$ \\
\hline Low & Low & Low & Constant & Unclear & Small & Cheap & Low \\
\hline Mobility & Reproduction & Value & Distribution & Boundaries & Size & Construction & Productivity \\
\hline \multicolumn{4}{|c|}{ RESOURCES } & \multicolumn{4}{|c|}{ RESOURCE SYSTEMS } \\
\hline \multicolumn{4}{|c|}{ GOVERNANCE SYSTEMS } & \multicolumn{4}{|c|}{ ACTORS } \\
\hline Government & NGOs & Property rights & Rules & History & Knowledge & Dependence & Technology \\
\hline Strong & Strong & Open & Established & A lot & A lot & High & Advanced \\
\hline $\begin{array}{l}\text { - Agriculture } \\
\text { - Tourism } \\
\text { - Fishing } \\
\text { - Conservation } \\
\text { - Pollution }\end{array}$ & $\begin{array}{l}\text { - Tourism } \\
\text { - Industry } \\
\text { - Farmer lobby } \\
\text { - Surfers } \\
\text { - Local fishers }\end{array}$ & $\begin{array}{l}\text { - Ocean water } \\
\text { - Nutrient flow } \\
\text { - River water } \\
\text { - Fisheries } \\
\text { - Beaches } \\
\text { - Aquaculture }\end{array}$ & $\begin{array}{l}\text { - Fishing } \\
\text { - Catchment } \\
\text { - Sewage } \\
\text { - Coral reefs } \\
\text { - Marine litter }\end{array}$ & $\begin{array}{l}\text { - Fishing } \\
\text { - Tourism } \\
\text { - MPAs } \\
\text { - Dive tourism } \\
\text { - Aquaculture }\end{array}$ & $\begin{array}{l}\text { - Fishing } \\
\text { - Forestry } \\
\text { - Tourism } \\
\text { - Catchment } \\
\text { - Coral reefs }\end{array}$ & $\begin{array}{l}\text { - Local fisher } \\
\text { - Sea grass } \\
\text { collector } \\
\text { - Hotel owner } \\
\text { - Tourist }\end{array}$ & $\begin{array}{l}\text { - Hotels } \\
\text { - Shipping } \\
\text { - Aquaculture } \\
\text { - Fisheries } \\
\text { - Hand fishing }\end{array}$ \\
\hline Weak & Weak & Private & None & Minimal & Minimal & Low & Basic \\
\hline
\end{tabular}

(Wedding et al. 2015), watersheds (Kroon and Brodie 2009, Álvarez-Romero et al. 2015), or marine conservation (Jentoft et al. 2007, Gruby and Basurto 2014). Additional work has focused on conceptualizing the challenges and complexities of coasts (Olsen 2003, Rochette et al. 2015, Campbell et al. 2016, Schlüter et al. 2019) or reviewing the contextual literature (Pittman and Armitage 2016), without providing a specific governance approach.

On the other hand, there is a large amount of literature focused on policy or management approaches. Topics include marine spatial planning (MSP; Portman et al. 2012, Vince 2014, van Tatenhove 2017), integrated coastal zone management (ICZM; Sekhar 2005, McKenna et al. 2008, Gallagher 2010, Hagan and Ballinger 2010, Portman et al. 2012), and approaches not specific to the coast such as ecosystem-based management, adaptation, and comanagement. We argue that these are not foundational theories, but synthetic applications that have been simplified into policy strategies.

Although policy discourses usually recognize coasts as singular spatially bound places and/or spaces, academic literature now suggests that a more diversified and plural reality exists across locations and for different people (Neumann et al. 2015). Taking coastal governance seriously should include moving beyond the notion of the "coast" as a singularly definable entity (Fig. 2). Instead, coastal areas can in part be understood by the heterogeneity of human connections and interpretations: as hubs of international trade, sites of regional governance and political influence, ecological hotspots, as well as centers for both urban and rural socioeconomic development. Figure 2 helps highlight the diversity of social-ecological characteristics that may be present in different coastal localities. Although the perspectives presented in Figure 2 only represent a limited view, we believe it is nonetheless useful for portraying the complexity of coastal systems that governance scholarship as evolved is attempting to address, and within which our current analytical tools are currently being applied.

Although much of scholarly literature and coastal governance practice draws on a body of natural resource governance theories, a synthetic overview and analysis that identifies their core claims and abilities for analyzing coastal systems is still lacking. In this article we aim to address this gap by attempting an overview of different theories, their main claims, origin, and core literature. In the discussion we compare focused theories versus more combinatory theoretical frameworks. We argue that each theory is a valuable analytical tool with unique strengths, and that environmental governance analysts should be familiar with how to use the various elements of this toolbox in constructive ways.

\section{METHODS}

Identifying theories to include in this study was done in two ways: first, through deliberation among coauthors and participants of the Land-Sea Interactions working group within the European Cooperation for Science and Technology (COST) Ocean Governance Network (https://www.oceangov.eu/; SP, ASc, NV, LS, ML, A-KH, MB). Initial working group discussions took place in June 2018 during the Third International Symposium on Ocean Governance for Sustainability in Aveiro, Portugal. The 
Table 1. Overview of theoretical literature on natural resource governance.

\begin{tabular}{|c|c|c|c|c|}
\hline Theory & $\begin{array}{l}\text { Foundational } \\
\text { literature }\end{array}$ & General synthesis literature & $\begin{array}{l}\text { Notable coastal empirical } \\
\text { literature }\end{array}$ & Core concepts \\
\hline Polycentricity & $\begin{array}{l}\text { (Polanyi 1951, Ostrom } \\
\text { 1972) }\end{array}$ & $\begin{array}{l}\text { (Ostrom 2010, Aligica and Tarko } \\
\text { 2012, Carlisle and Gruby 2019) }\end{array}$ & $\begin{array}{l}\text { (Gelcich 2014, Gruby and } \\
\text { Basurto 2014, van Leeuwen } \\
\text { 2015, Abe et al. 2016, } \\
\text { Carlisle and Gruby 2018) }\end{array}$ & $\begin{array}{l}\text { Decentralization } \\
\text { Multiple centers of decision making }\end{array}$ \\
\hline $\begin{array}{l}\text { Network } \\
\text { governance }\end{array}$ & $\begin{array}{l}\text { (Whetten and Rogers } \\
\text { 1982, Kaufmann et al. } \\
\text { 1986, Rhodes 1988) }\end{array}$ & $\begin{array}{l}\text { (Jones et al. 1997, Thatcher 1998, } \\
\text { Duit and Galaz 2008, Robins et al. } \\
\text { 2011, Klijn and Koppenjan 2012) }\end{array}$ & $\begin{array}{l}\text { (Green et al. 2011, Duval- } \\
\text { Diop et al. 2014, Pittman } \\
\text { and Armitage 2017, 2019) }\end{array}$ & $\begin{array}{l}\text { Actors and rules } \\
\text { Actor connectivity } \\
\text { Interdependencies } \\
\text { Problem frames } \\
\text { Interactions and relationships }\end{array}$ \\
\hline $\begin{array}{l}\text { Collective action } \\
\text { theory }\end{array}$ & $\begin{array}{l}\text { (Olson 1965, Ostrom } \\
1990,2007,2009)\end{array}$ & $\begin{array}{l}\text { (Ostrom 1998, Cox et al. 2010, } \\
\text { Poteete et al. 2010, Gyau et al. } \\
\text { 2014, Holahan and Lubell 2016) }\end{array}$ & $\begin{array}{l}\text { (Basurto et al. 2013, 2016, } \\
\text { Afroz et al. 2016, Partelow et } \\
\text { al. 2018a, Chavez Carrillo et } \\
\text { al. 2019) }\end{array}$ & $\begin{array}{l}\text { Institutions and institutional change } \\
\text { Bounded rationality } \\
\text { Commons theory (shared resource) } \\
\text { Social-ecological systems }\end{array}$ \\
\hline $\begin{array}{l}\text { Governmentality/ } \\
\text { environmentality }\end{array}$ & $\begin{array}{l}\text { (Foucault 1980, } \\
\text { Burchell et al. 1991, } \\
\text { Agrawal 2005a, b) }\end{array}$ & $\begin{array}{l}\text { (Burchell et al. 1991, Scott 1998, } \\
\text { Darier 1998, Luke 1998, Rose et al. } \\
\text { 2006, Malette 2009, Bevir 2010, } \\
\text { Fletcher 2010, 2017) }\end{array}$ & $\begin{array}{l}\text { (Hanson 2007, Song 2015, } \\
\text { Albert and Vasilache 2018, } \\
\text { Satizábal 2018) }\end{array}$ & $\begin{array}{l}\text { Power/knowledge } \\
\text { Discourse theory } \\
\text { Government as social technology } \\
\text { Government at a distance }\end{array}$ \\
\hline $\begin{array}{l}\text { Multilevel } \\
\text { governance theory }\end{array}$ & (Marks 1993) & (Stephenson 2013) & $\begin{array}{l}\text { (Anh et al. 2011, Basurto } \\
\text { 2013a, } b \text {, Gruby and Basurto } \\
\text { 2014, Van Tatenhove 2015, } \\
\text { Ringbom and Joas 2018) }\end{array}$ & $\begin{array}{l}\text { Vertical integration } \\
\text { Social organization } \\
\text { Public administration }\end{array}$ \\
\hline $\begin{array}{l}\text { Interactive } \\
\text { governance theory }\end{array}$ & $\begin{array}{l}\text { (Kooiman 1993, 2003, } \\
\text { 2008, Kooiman et al. } \\
\text { 2005, 2008) }\end{array}$ & $\begin{array}{l}\text { (Jentoft 2007, Kooiman et al. 2008, } \\
\text { Song et al. 2018) }\end{array}$ & $\begin{array}{l}\text { (Bavinck et al. 2005, } \\
\text { Kooiman et al. 2005, } \\
\text { Chuenpagdee 2011, Defeo } \\
\text { and Castilla 2012) }\end{array}$ & $\begin{array}{l}\text { Governability } \\
\text { Modes of governance } \\
\text { Orders of governance } \\
\text { Elements of governance } \\
\text { Governing interactions }\end{array}$ \\
\hline $\begin{array}{l}\text { Adaptive } \\
\text { governance }\end{array}$ & $\begin{array}{l}\text { (Gunderson 1999, } \\
\text { Dietz et al. 2003, } \\
\text { Folke et al. 2005) }\end{array}$ & $\begin{array}{l}\text { (Rijke et al. 2012, Chaffin et al. } \\
\text { 2014, Koontz et al. 2015, Chaffin } \\
\text { and Gunderson 2016, Cox and } \\
\text { Schoon 2019) }\end{array}$ & $\begin{array}{l}\text { (Gunderson and Light 2006, } \\
\text { Ashlin 2011, Meek et al. } \\
\text { 2011, Österblom and Folke } \\
\text { 2013, Tuda et al. 2019) }\end{array}$ & $\begin{array}{l}\text { Adaptation } \\
\text { Resilience thinking } \\
\text { Panarchy } \\
\text { Social-ecological systems }\end{array}$ \\
\hline $\begin{array}{l}\text { Evolutionary } \\
\text { governance theory }\end{array}$ & $\begin{array}{l}\text { (Van Assche et al. } \\
\text { 2014, Beunen et al. } \\
\text { 2015) }\end{array}$ & --- & $\begin{array}{l}\text { (Schlüter et al. 2019, 2020b, } \\
\text { Partelow and Nelson 2020, } \\
\text { Van Assche et al. 2020a) }\end{array}$ & $\begin{array}{l}\text { Institutional economics } \\
\text { Social systems theory } \\
\text { Path dependency } \\
\text { Evolutionary biology } \\
\text { Discourse theory } \\
\text { Multilevel governance }\end{array}$ \\
\hline
\end{tabular}

discussions focused on: what are the challenges, options, and the role of science in ocean governance? Our group identified one core challenge being that no specific coastal governance theories exist, and that most environmental governance theories have evolved through empirical support on terrestrial systems. Our discussions evolved into a research question: what environmental governance theories have been foundational and influential for coastal scholars? Our goal was to identify and review the core theories, and over the period of the conference we developed an initial list of theories.

Following the conference, confirmation of our initial list of theories was done through a literature search in the academic database SCOPUS using the search string ("natural resource*" AND "governance"), and sorting by "Review" documents. This resulted in 277 documents; each title and abstract was assessed by the lead author for additional theories. A second search string ("natural resource*" AND "governance" AND "theory") was then used, resulting 325 documents to inform our final list. We acknowledge that this review is not fully exhaustive or inclusive; there are certainly more theories and frameworks with varying degrees of links to natural resource governance scholarship (see Ansell and Torfing 2016, Cox et al. 2016, Nunan 2019). Part of our inclusion criteria was also diversity, to show a spectrum of theories available with different perspectives and disciplinary origins. Our aim was to provide an accessible summary of some of the core theories that have been foundational in environmental governance scholarship, as well as to highlight more recent developments. To do this, we wanted to ensure that we had an expert in each theory and its application. We brought together additional coauthors, each whom is specialized in one or multiple theories and their application to coastal governance (DA, JP, RG, $\mathrm{KC}, \mathrm{ASo}, \mathrm{KvA})$.

With our analysis we attempt to highlight the unique value of each theory, but also to compare them in a way that shows the value and unique perspective each takes. In doing so, we provide a qualitative and interpretative synthesis of selected foundational literature, as well as any synthesis literature and notable case studies applying each theory to coastal systems. The order of theories is chronological and based on the year in which a foundational theory emerged. A synthesis is provided (Table 1) referencing the literature as well as the core concepts, variables, or processes integral to each. These were interpretively assessed based on both the foundational and synthesis literature available, each provided by the expert coauthors, and then reviewed by all 
authors because many of the authors are familiar with multiple theories presented.

We attempted to undertake this process inductively, and then compare what core concepts were present in each theory. In the end we decided to not have a core set of criteria to analyze each theory because it would be too restrictive, but rather to analyze the strength of each theory separately. The formal comparison was limited to their emergence over time and focused versus combinatory orientation, as we explain below. We also recognize that the "Core concepts" column in Table 1 is not a comprehensive depiction of each theory, but nonetheless provides useful references for basic comparison.

\section{SYNTHESIS OF GOVERNANCE THEORIES AND THEIR APPLICABILITY}

\section{Polycentricity}

Polycentric governance was introduced by Vincent Ostrom (Ostrom et al. 1961) to describe metropolitan-area governance characterized by multiple, overlapping political units or decisionmaking centers. These centers in a polycentric system operate with a degree of autonomy but also take one another into account through processes of cooperation, competition, conflict, and conflict resolution that can lead to self-organizing tendencies if general rules provide appropriate incentives and constraints (Ostrom and Ostrom 1991, Aligica and Tarko 2012). Empirical research on polycentricity in metropolitan governance challenged the then prevailing view in the political and economic sciences favoring "monocentric," i.e., centralized, political order, by revealing the potential for polycentric systems to operate as efficiently as centralized arrangements when they function as a system (Ostrom and Parks 1999). In the field of natural resource systems, polycentric governance emerged in the 1990s through the groundbreaking research of Elinor Ostrom, who found that robust institutions governing common-pool resources tend to be "organized in multiple layers of nested enterprises" (Ostrom 1990:101), a characteristic of polycentric systems. Recognizing that most natural resource systems cross political boundaries, and that few governance systems are purely centralized or decentralized in practice, environmental governance scholars have increasingly turned to the concept of polycentricity (Heikkila et al. 2018). One reason polycentricity is compelling is that its theoretical development has drawn partly from living systems theory. In this regard, polycentric governance systems have been characterized as complex adaptive systems (Andersson and Ostrom 2008) with emergent, self-organizing properties. With their diverse array of decision-making centers with different (and ideally complementary) capacities, polycentric governance systems may be capable of continually evolving and reconfiguring as necessary or desirable (Carlisle and Gruby 2019). Accordingly, scholars have attributed different advantages to polycentricity, mostly within three broad categories: (i) enhanced capacity to adapt to change; (ii) mitigation of risks associated with the failure of any single governance actor or policy because of redundant governance actors and policies; and (iii) the production of institutions that are a good "fit" to ecological and social context (Carlisle and Gruby 2019). An important research frontier is distinguishing among different types of polycentric governance systems and the characteristics associated with their advantages and pathologies in diverse contexts (Carlisle and Gruby 2018, Morrison et al. 2019).
Although the concept of polycentric governance has not been specifically adapted or tailored for coastal systems, a growing number of coastal and marine governance studies have employed the concept, including scholarship on marine protected areas (Gruby and Basurto 2014, Morrison 2017); large marine ecosystems (Abe et al. 2016, Chen and Ganapin 2016); small-scale fisheries (Gelcich 2014, Carlisle and Gruby 2018); marine shipping (van Leeuwen 2015); and climate change, ocean acidification, and marine biodiversity (Galaz et al. 2012) and the role of power (Morrison et al.2019). The usefulness of the concept in such studies stems, in part, from the scale and complexity of coastal systems, which tend to span multiple jurisdictions, e.g., watersheds, include mobile and transboundary resources, e.g., migratory fish, and encompass many users and decision-making centers with diverse and often competing goals. Understanding and informing governance of such complex systems requires a theoretical framework that embraces complexity and redundancy and enables the analyst to search for order in apparent chaos. Herein lies the overarching power of polycentricity for coastal systems. In a more specific sense, the theory holds utility for both descriptive and diagnostic (problem driven) forms of analysis.

Descriptively, polycentricity helps analysts identify constituent elements of complex coastal governance systems as they exist in practice. Theory directs analysts to ask: who/what/where are the decision-making centers, and what are their roles in governance? Such centers are not only formal bodies; rather, they can be any organization or individual making and enforcing rules with some autonomy, including informal organizations such as resource user groups (McGinnis 2011, Carlisle and Gruby 2019). Rather than focusing solely on rules-in-form and actors with formal authority, polycentricity requires considering rules-in-use, the role of nongovernment/nonstate actors, and their interactions at all levels of political and social organization. The role of power, defined by Morrison and colleagues (2019) as the uneven capacity of actors in a polycentric system to influence goals, processes, and governance outcomes, is another important and underexamined aspect of polycentric governance systems that may explain why certain systems perform better than others, despite structural similarities (Morrison et al. 2019). This helps develop a more complete picture of relevant actors, institutions, interactions, and processes influencing governance.

Although in early stages of development, theoretical work on polycentric governance could be applied diagnostically to identify deficiencies in a coastal governance system. For example, Carlisle and Gruby (2018) devised a theoretical model of a functional polycentric governance system to diagnose governance deficiencies implicated in the decline of a small-scale coastal fishery in Palau. Using the model as the "ideal type," empirical attributes and enabling conditions were identified as present or absent in the case. Combined with a deeply contextualized historical analysis, they explained limited governance functionality and identified advantageous characteristics for enhancement. As theory improves, this method can inform applied research and institutional design.

\section{Network governance}

Network approaches have been examined in the literature since the 1970s (Whetten and Rogers 1982, Kaufmann et al. 1986, Rhodes 1988, Thatcher 1998, Klijn and Koppenjan 2012). Klijn and Koppenjan (2012) suggest three historical research traditions 
linked to the development of network governance theory, including policy networks, service delivery and implementation, and managing networks. Additionally, network analysis is often used as a methodological tool to analyze governance networks. As summarized by Thatcher (1998), and synthesized be others (Jones et al. 1997, Duit and Galaz 2008, Robins et al. 2011), core tenets of network governance theory emerged as a counter to the monopolistic view of centralized states as the entities doing all the governing, toward a view of many actors interacting in decentralized and pluralistic ways through coordinated networks (Bodin 2017). These include or may exist as formal or informal structures, or within social hierarchies, and provide alternative means of governing outside of states and markets. Furthermore, network governance theory also reflects ideas of how information is diffused, as well as how social learning and cultural exchange takes place. Much of the empirical analysis has taken place between either state and nonstate actors, actors tasked with implementation or diffusion of information or polices, as well as coordination problems between actor groups or organization (Klijn and Koppenjan 2012). A central tenet of network governance theory is that the characteristics or properties of governance networks will influence the outcomes from governance processes. However, it is not only the quantity of connections that matter, but also the types of connections, the structure of the network, and how important those connections are between the actors involved. Some governance systems have been analyzed as overnetworked or having "governance without government" (Pierre and Peters 2005:40), which some may view as undesirable.

More recently, network governance has focused on environmental management (Newig et al. 2010, Green et al. 2011, Robins et al. 2011, Duval-Diop et al. 2014, Pittman and Armitage 2017, 2019). As Newig et al. (2010) point out, network governance has become useful for its "potential to integrate and make available different sources of knowledge and competences and to foster individual and collective learning" for managing shared natural resources. Furthermore, in the coastal context, Pittman and Armitage (2019) argue that, in theory, improved collaboration via networks in governance increases "flexibility in the face of change and promotes inclusiveness and legitimacy" (p. 62). Ultimately, networks that link actors across scales are primarily a reflection of the social relational features and arrangements that influence governance outcomes (e.g., Bodin and Crona 2009). In this regard, Alexander et al. (2016) identify three useful "waypoints" that can help researchers and practitioners explore networks in a systematic manner, including (1) reflecting on the specific ways in which governance actors are embedded in a broader constellation of stakeholders, rights holders, and decision makers; (2) examining the diverse values and interests of governance actors and the implications for governance outcomes; and (3) reflecting on the specific structure and process dynamics of social relational networks given the implications for decision making.

\section{Collective action theory}

Collective action theory was introduced by Olson (1965), and then later popularized by Elinor Ostrom in Governing the Commons (Ostrom 1990) as a theory to explain why many communities using natural resources do not always experience overexploitation, i.e., for common-pool resources, or underprovisioning, i.e., for public goods, a so-called tragedy of the commons (Hardin 1968).
Building on Governing the Commons, an entire school studying the commons has emerged (Ostrom 1998, 2007, 2009, Cox et al. 2010, Poteete et al. 2010; https://iasc-commons.org/). The theory hypothesizes a positive relationship between groups that are able to take effective collective action and the resulting social and environmental outcomes. The theory aims to understand how and why people cooperate through self-organization processes (i.e., a collective action) and what social (e.g., leadership; group size; knowledge; social capital; dependence) and ecological variables (e.g., resource mobility; system size; growth and replacement rates) influence self-organization (Ostrom 2007, 2009).

The variables identified as influencing collective action are generally those compiled in Ostrom's social-ecological systems framework (Ostrom 2009, McGinnis and Ostrom 2014, Partelow 2018). Ultimately, the theory aims to explain why self-organized collective action can lead to more desired social and ecological outcomes, e.g., sustained provision or use, in some cases, and in others not. Ostrom's work on the framework has evolved into a commons and collective action take on what is now much broader social-ecological systems discourse. Collective action theory, focusing on community-based solutions in resource governance, is often juxtaposed as a third understanding, or governance perspective on, how to resolve resource appropriation and provision dilemmas through governance, which has historically been viewed as a problem of aligning individual and group interests. It is an alternative to other popularized approaches, such as privatization or top-down state enforcement to solve the same problems. Collective action theory has also been used to understand the self-organization of social movements and activism related to many issues including those related to the environment (Lubell 2002).

Collective action theory is useful for assessing the status of governance by identifying what variables may be enabling or hindering self-organization processes. More than 30 variables have been identified to be critical for collective action to occur (Agrawal 2001). All those factors have been largely discussed in the literature, and Cox et al. (2010) provide a good summary for each variable with other synthesis literature looking at practical applications (Gyau et al. 2014). Relating to coastal systems, collective action theory is most prominently applied to small-scale fishers and the management of inshore resources (Lozano and Heinen 2016, Chavez Carrillo et al. 2019). However, it is also used to understand other collective action problems in the marine realm such as certification (Foley and McCay 2014), freshwater resources (Afroz et al. 2016), aquaculture (Partelow et al. 2018b), protected areas (Gruby and Basurto 2014), and coral reef degradation (Schlüter et al. 2020a).

\section{Governmentality / environmentality}

The term governmentality was formulated by Michel Foucault in the late 1970s and early 1980s (Burchell et al. 1991). Governmentality refers to the "conduct of conduct" (Bevir 2010) and "captures the way governments and other actors draw on knowledge to make policies that regulate and create subjectivities" (Bevir 2010:423). Foucault was particularly interested in the practices and technologies employed by modern, liberally organized and territorially defined states for regulating, disciplining, and thus governing social reality. Governmentality suggests an inseparable and iterative relationship between a 
governing body and those being governed that is coshaped by technologies of enforcement in relation to objects of shared interest, such as security or economy. Through the employment of power, knowledge, and discourse, subjectivities are created in which the subjects themselves are indeed willing to be governed. Environmentality combines Foucault's concept of biopower with the concept of governmentality, spotlighting social interaction with the natural world as the object of shared interest. In other words, power, discourse, and knowledge are tools of government that iteratively coshape the willingness of subjects (the self) to be governed in how they use, think about, and/or interact with the environment. Imaginaries of and discourses surrounding the natural environment, e.g., nature is beautiful; nature is being destroyed; nature is endless, in combination with power/ knowledge, e.g., the role knowledge plays in structuring hierarchies between interpersonal relationships and within society, shape one's willingness to act in a governed way toward the environment. These "technologies," e.g., discourse or power/ knowledge, shape and are being shaped by the governed, and at the same time governing the subject. Environmentality as a concept has been advanced by scholars, such as Agrawal (2005a) through a comparative analysis of community-based forest management in Northern India, and Scott (1998) focusing on the political economy of Tanzania's agriculture. Further literature has focused on coastal issues (Hanson 2007, Song 2015, Satizábal 2018).

Albert and Vasilache (2018) use governmentality outside the context of modern nation states, instead assessing how a largely uninhabited, oceanic, and formerly ungovernable border zone in the Arctic was made governable. Three processes are regarded as decisive: (1) the framing of the Arctic in international media and policy fora as a regional and governable space (as opposed to international, ungovernable, and wild); (2) the normalization and securitization of the Arctic through systematic multidisciplinary knowledge production on all facets of this particular space, now predictable and ordered; and (3) the unleashing of its economic potential by including it into a highly internationalized liberal political economy.

The case above demonstrates the usefulness of governmentality in studying coastal governance, becoming governable when they (1) move, in public and government attention, from marginal nonplaces to the center of political, economic, and thus governance attention; (2) are ordered, securitized, and normalized through the employment of systematically collected expertise on the coastal zone as a space in itself, not the margin of another space; and (3) as new profit frontiers become part of the political economy (considered worth its own key word in government statistics). This heuristic places focus on power contestations, e.g., who influences those processes, and who is influenced by them, on who are the potential winners and losers, and, in a first instance, privileges the state as governing entity. It nevertheless invites the opposite question about assessing the governmentality of marginal coasts, of little state interest or attention. Who governs there, through the employment of which discourses, knowledge, and securitizing technologies?

\section{Multilevel governance (MLG) theory}

While multilevel perspectives go further back (van den Eeden and Hüttner 1982), formal multilevel governance (MLG) theory emerged from policy debates and the restructuring of the European Union under the Maastricht Treaty in 1992 (Marks 1993), to examine the vertical integration of national and international politics. Stephenson (2013) provides an overview of MLG, its main uses, and applied research. In natural resource scholarship, MLG has expanded the range of levels that are interconnected through governance, often examining the relationship between communities, regions, national and international policies. Because formal natural resource management policies are often formulated at the regional or national level, much of the scholarship drawing on MLG has focused on how higher level policies trickle down to be implemented in practice at the local level. MLG hypothesizes that the better the vertical integration between the multiple levels of governance, the more effective it will be, with the assumption that top-down driven governance can work well if effectively integrated across levels. Thus, MLG emphasizes that there are multiple levels where governance plays out, recognizing that there are often states who oversee natural resource management policy from the top-down, regional, or municipal authorities tasked with implementation, but also local communities who face the reality of policies and who may have self-organizational capacity for governance. MLG aims to provide a theoretical framework that recognizes the vertical integration of the different organizational levels of governance.

MLG is useful for questions of how public administration of environmental policies involve multiple actors at different social organization levels, and how those configurations can be vertically integrated or create challenges from a lack of integration, e.g., communication or implementation. Research questions that seek to understand the views, perceptions, goals, and/or motivations at different policy levels may find MLG useful, as well as examining the difficulties with top-down government strategies or why local governance is mismatched with regional, national, or international policies and goals. The implementation of the FAO Small-Scale Fisheries Guidelines is a useful example of how international frameworks for governance are viewed, interpreted, and implemented (or not) in countries and local fisheries around the world (Jentoft et al. 2017, Sabau 2017, Chavez Carrillo et al. 2019, Song et al. 2019a). Similarly, many national level natural resource management strategies such as Extractive Reserves (RESEX) in Brazil (Santos and Brannstrom 2015, Partelow et al. 2018a), Responsible Fishing Areas in Costa Rica (Lozano and Heinen 2016, Chavez Carrillo et al. 2019), or aquaculture policies in Vietnam (Anh et al. 2011), exhibit heterogeneous implementation processes and outcomes at the local level despite higher level standardization. MLG can assist in analyzing why this occurs, because of vertical integration challenges within administrative, legal, and political processes across levels.

MLG is useful for identifying where governance challenges might be occurring within and/or between social organizational levels. Van Hoof et al. (2012) demonstrate how MLG can be used to unpack the state-centered marine policy approach of the European Union, as attempting to integrate decision and policy making across subnational and national levels. These authors suggest that the regional level should be the focus level for EU policy development, highlighting the need for tailoring marine policies through regionally structured cooperation in the EU (i.e., Baltic Sea vs Mediterranean Sea should involve different subnational actors and approaches), but that many of the decisions are still 
made at the member state level, creating challenges for the regionalization of the Commons Fisheries Policy and the Marine Strategy Framework Directive to adapt to the regional context. Challenges with science-policy integration in the EU Commons Fisheries Policy have been similarly explored by Wilson (2009).

\section{Interactive governance theory (IGT)}

Kooiman (2016) provides a conceptual overview of interactive governance theory (IGT), along with the associated concept of governability, building on previous work (Kooiman 1993, 2003, $2008)^{[1]}$. Interactive governance is defined as "the aggregate of governing activities carried out by societal actors in response to public needs and visions" (Kooiman 2016:29). It takes place not through single, do-it-alone efforts, but via interactions between multiple actors in different societal realms (state, market, and civil society). Governability provides "a conceptual basis for assessing and improving the interactive governance of natural resource systems" (Kooiman et al. 2008:2). It consists of two dimensions, the capacity for governance, and the quality of governance (Chuenpagdee and Jentoft 2015). The former is instrumental in focus, while the latter adds a normative dimension, asking whether governance lives up to certain standards or principles.

Governability suggests a balance between needs of the specific societal system being governed (SG) and the capacity of the governing system (GS) plus the totality of governing interactions (GI) to deliver those needs. IGT proposes a model to analyze this dynamic in terms of elements, modes, orders, and interactions, assuming that features of any societal system, namely its diversity, complexity, and dynamics, are generally on the increase. Elements include images (mental pictures guiding processes), instruments (available means for governing interactions), and actions (willpower available for governing interactions). Modes of governance include self- (e.g., actors take care of themselves), co(e.g., societal parties join hands with a common purpose), and hierarchical (e.g., top-down) styles of intervention. Orders are divided into first-order (where people and organizations interact), second-order (institutional arrangements), or meta-order (feeds, binds, and evaluates governance). Interactions are of three types: interferences (open and spontaneous in nature), interplays (semiformalized and "horizontal" in nature), and interventions ("vertical" and formalized in nature).

IGT has been extensively applied in coastal fisheries and aquaculture systems, most notably in the books Fish for Life (Kooiman et al. 2005), Governability of Fisheries and Aquaculture (Bavinck et al. 2013), Interactive Governance for Small-Scale Fisheries (Jentoft and Chuenpagdee 2015) and its practical guide (Bavinck et al. 2005), among others (Defeo and Castilla 2012). Chuenpagdee et al. (2008) broadened the perspective to coastal zones, arguing that coastal zones are normally characterized by high natural and social diversity, complexity, and dynamics. The authors conclude that the governability thereof is normally moderate to very low: "An integrated, holistic, systematic and transparent approach to coastal zone management is difficult to attain" (Chuenpagdee et al. 2008:15), due to different interests and objectives, and difficulties developing a shared way forward. Coasts possess their own constellation of problems and opportunities; there are no panaceas. In line with adaptive governance thinking, "learning" is an important feature of governance in the current age, as is a return to the principles underlying all governance activity.
A unique feature of IGT is first identifying the unique characteristics and challenges of the system to be governed, i.e., the problems and opportunities it presents, and then assessing the social organizational factors of governance. The notion of "fit" is essential: does the governing system and the set of governing interactions correlate with the needs of the system to be governed, or do they obstruct appropriate action? Do actions, instruments, and images of governing match with one another and provide a coherent whole?

While fit and functionality are important, conflict and power are not ignored. Kooiman (2016:45) argues that "there are no interactive governance or issues of governability without attention for power differentials and sources of conflict." Similarly, Jentoft and Chuenpagdee (2015:739) emphasize that "from a governability perspective, both the restrictive and enabling functions of power must be investigated." Politics are believed to be a crucial dimension of governance, as it is "basically in political arenas and public spheres where the 'destinies' of social fields ... are decided" (Kooiman 2016:45). Here, societal concerns such as ecosystem health, social justice, employment, and food security are translated into governing objectives.

Jentoft and Chuenpagdee (2013) proposed a governability assessment framework. It consists of four steps, first defining a specific problem and its "wickedness" (Rittel and Webber 1974), and then diagnosing the system being governed, the governing system, and the set of interactions. Deliberately holistic in scope, it reduces complexity by pointing out where to look (targets), what to look for (features), and what to look at (measures). The result is a matrix containing all information necessary for a comprehensive governability assessment.

\section{Adaptive governance}

Adaptive governance theory emerged in the late 1990s (Gunderson 1999), but was popularized by the book Panarchy (Gunderson and Holling 2002), in the context of commons by Dietz et al. (2003), and later in social-ecological systems (Folke et al. 2005). Chaffin et al. (2014) provide a detailed history and overview of adaptive governance scholarship, which has continued into the present (Cvitanovic et al. 2015, Schultz et al. 2015, Chaffin and Gunderson 2016). Adaptive governance has been referred to as a vehicle for putting resilience theory into practice (Garmestani and Benson 2013) with the aim to reduce uncertainty through iterative and continual learning. Theoretically, adaptive governance hypothesizes that the more adaptive a governance system is to social-ecological system functioning and change, the more resilient that governance system is, making it more likely to achieve normative goals, e.g., sustainability.

Adaptive governance is premised on understanding how formal institutions, informal networks, and individuals at multiple scales are linked for resilient collaborative environmental management (Gunderson and Holling 2002). Folke et al. (2005:444) note "that adaptive governance is operationalized through adaptive comanagement systems and that the roles of social capital, focusing on networks, leadership, and trust, are emphasized in this context." In this regard, the literature on adaptive comanagement (Olsson et al. 2004, Armitage et al. 2009) draws attention to the learning (experiential and experimental) and collaboration (vertical and horizontal or networks) required to generate better outcomes in the context of complex social-ecological systems. As 
with most broad or combinatory governance theories, however, there is no clearly fixed definition of adaptive governance. All attempts to define or describe it emphasize the interdependencies in changes that occur between social and ecological systems, while also recognizing their complexity. This includes conceptualizing environmental and natural resource systems as linked socialecological systems (Berkes et al. 2003).

There are many useful features of adaptive governance relevant for coastal change and complexity. These features emphasize the importance of collaboration among diverse actors and interests, as well as institutions that are flexible and nested. The adaptive dimension of governance also draws attention to the importance of the deliberative processes that are required to build understanding based on multiple knowledge systems, encourage trust through repeated interactions, and finally, to encourage social (or collective) learning processes and continuous feedback (Dietz et al. 2003, Folke et al. 2005, Armitage and Plummer 2010). Adaptive governance is particularly oriented toward studying the capacity of a governance system to adapt to new (ecological and social) system conditions, given those changes that may stem from climate change, overfishing, or other issues that make coastal systems dynamic. As such, in coastal systems, adaptive governance has been applied to diverse empirical settings, including disaster management (Adger et al. 2005), marine transboundary governance (Tuda et al. 2019), the response to changes in fisheries or fisheries management (Cinner et al. 2011), and coping in response to climate change (Hughes et al. 2007).

\section{Evolutionary governance theory (EGT)}

Evolutionary governance theory (EGT), introduced by van Assche et al. (2014) and Beunen et al. (2015), understands governance as a process of constant evolution. Stability is presented as illusory, as surface features consistently hide underlying change, while radical transitions, as ab ovo institutional design, are considered impossible, because transformation requires a starting point. Evolution for EGT is always coevolution, emphasizing configurations of actors and institutions, power and knowledge, and institutional formal and informal rules. Each configuration can only be understood through its previous state, its linkage, and its coevolution with other elements. Following Foucault, the evolution of power relations in governance can only be understood by grasping the coevolution with forms of knowledge, including expert knowledge, but also narratives, concepts, images, and local or traditional knowledge. Similarly, the evolution of institutions (laws, policies, and plans as formal institutions, plus informal institutions) can only be understood through the coevolution with actors (individuals, groups, organizations). The configurations themselves coevolve, bringing every element of governance potentially in contact with every other. Potentially is a key word because the always unique development paths of a governance configuration, a path shaped by strategy, coevolution, and contingency, creates certain elements and couplings between them, not others.

A primary contribution of EGT is the evolutionary perspective, bringing a temporal dimension to the understanding of governance. EGT presents a new conceptual architecture to governance analysis and borrows elements from existing theories: social systems theory, institutional economics, poststructuralism, evolutionary biology, and of course previous governance theories, cognizant of path dependence, coevolution, and issues of institutional capacity. Prior system states influence future states through a wide variety of mechanisms, ranging from patterns of elements and their interactions to modes of interpretation and transformation. Strategy is not rendered irrelevant yet takes on the character of both narrative and institution (Van Assche et al. 2020b).

Its roots in social systems theory and poststructuralism entail a more socially constructed reality, where sets of knowledge, ideas, and narratives act as a social technology creating power hierarchies and thus governing the reality of how society is organized. Institutions, especially complex ones such as plans, are shaped by knowledge, rely on knowledge for impact, and compete with other types of knowledge for prime position in the definition of problems, solutions, and methods both inside and outside the configurations of governance. One could also understand EGT's main contribution as the mapping of a new middle ground between laissez faire, laissez passer approaches, and on the other hand beliefs in social engineering: path creation is possible, strategy is possible, comprehensive policies are not a pipe dream, yet what can be achieved will differ per governance path, and hinge on the context it operates in. EGT is not normative, and presents governance as always multilevel, polycentric, and always producing patterns of inclusion and exclusion.

EGT has been applied in different contexts: rural development (e.g., Van Assche and Hornidge 2015), shoreland development (Radomski and Van Assche 2015), natural resource management (Van Assche et al. 2017), coastal governance (Partelow and Nelson 2020, Schlüter et al. 2020b), and others (special issues in Marine Policy, Land Use Policy, and Journal of Environmental Policy \& Planning). This step-wise development of EGT placed its understanding of governance in social-ecological systems, becoming more sensitive to the material context of a governance path. In current coastal governance, material dependencies, effects of material environments, create unobserved interdependencies, which require unique forms of observation and dedicated coastal governance arenas (Van Assche et al. 2020a). For EGT, both layering and gaps mark coastal governance.

\section{DISCUSSION}

\section{Building a toolbox for governance analysis}

Environmental governance theories provide diverse lenses attempting to explain social-ecological realities, whether on the coast or in other systems. Generally, theories are useful if they help us explain what we observe, and there are often multiple if not many useful explanations for observed phenomena. More specifically, we can use each theory to help answer different research questions, but no single theory is or will be sufficiently comprehensive. We believe healthy and constructive scholarship has multiple theories coinciding, supporting, and/or contrasting themselves in a field. Nonetheless, some important questions can be reflected on by governance scholars: how have these theories been useful in establishing current environmental governance thinking, in research, teaching, and practice? Do the starting values motivating the initial theory as well as its current use-value differ between theories? Do we want more or less theory or theoretical framework development? These questions are not 
about the degree to which each theory is correct or not in explaining observations; instead, we are interested in how and why they have evolved and shaped intellectual thinking and environmental governance practice.

We argue that there is significant value in viewing governance problems from different perspectives, whether conceptual or theoretical. Similarly, theories link to methodological discussions and diversity, i.e., how can we measure particular attributes of a system in different ways? Each theory suggests (perhaps implicitly) a focal unit of analysis. This may relate to a particular focus on certain levels within a scale, e.g., spatial, temporal, and administrative (Cash et al. 2006, Glaser and Glaeser 2014), its epistemological perspective, i.e., positivistic or constructivist, its focus on agency versus system structures, processes versus outcomes, or its disciplinary orientation. Having a diverse theoretical toolbox to examine governance processes and challenges, we argue, is essential to foster a diverse multi and interdisciplinary field needed to build a more complete understanding of environmental governance through multiple ways of knowing. This, we argue, can enable environmental governance to strengthen as a field of scholarship, but also assist individual analysts and practitioners in selecting appropriate theoretical tools or approaches for the research or policy questions at hand to improve governance.

We have recognized through considerable deliberation that it is difficult to formally compare diverse theories based on their claims or constituent components. Nonetheless we have attempted to portray the generic evolution of the theories over time and by field or discipline (Fig. 3). Figure 3 provides a very basic conceptualization of environmental governance thinking since the 1960s based on our simplistic heuristic understanding. We highlight the different schools of thought as well as some key concepts and literature that have been influential. In doing so, we have categorized the theories into two groups for further comparison: (1) focused theories and (2) combinatory theories and frameworks. Although this categorization is somewhat arbitrary, it shows the temporal evolution of environmental governance scholarship, and is a simple way to broadly group them for further comparison below. This highlights a trend toward, we believe, collaborative knowledge production, systems thinking, and interdisciplinarity. For example, an interesting effort is underway to bridge governmentality and IGT via a revamped notion of governability (see Song et al. 2018). It is important to state again that this analysis is not a value judgement of particularly theories, but rather an attempt to assess the field's progression and status of our current toolbox.

We recognize that this analysis is not fully exhaustive or inclusive of all theories, concepts, and influential literature (i.e., Fig. 3). However, we hope to encourage scholars to continue thinking in similar ways about the field's history, status, and trajectory, while encouraging governance analysts to expand their own toolboxes. We also believe it is important for the field, especially for early career scholars and students, to understand this history and diversity so they can make their own interpretations and begin constructively building on the past and exploring new paths forward for environmental governance through constructive encouragement, reflexivity, collaboration, and creativity. Continuing below, we discuss the specific strengths of each theory, as either focused or combinatory. For example, earlier governance theories often focus on single issues with core theoretical hypotheses, like collective action or polycentric governance. More recent approaches are more combinatory, aiming to better understand the holistic complex picture. We have used the context of coastal systems to do this, providing empirical examples where each theory can be shown as applicable and analytically useful. We divide the theories into those that have a genuine theoretical core (focused hypotheses), as focused theories to be compared, and those that are a combination.

Fig. 3. Simplified heuristic conceptualization of the disciplinary origins of environmental governance theories (orange) and related concepts (blue) since the 1960s. Selected influential literature references are also shown.

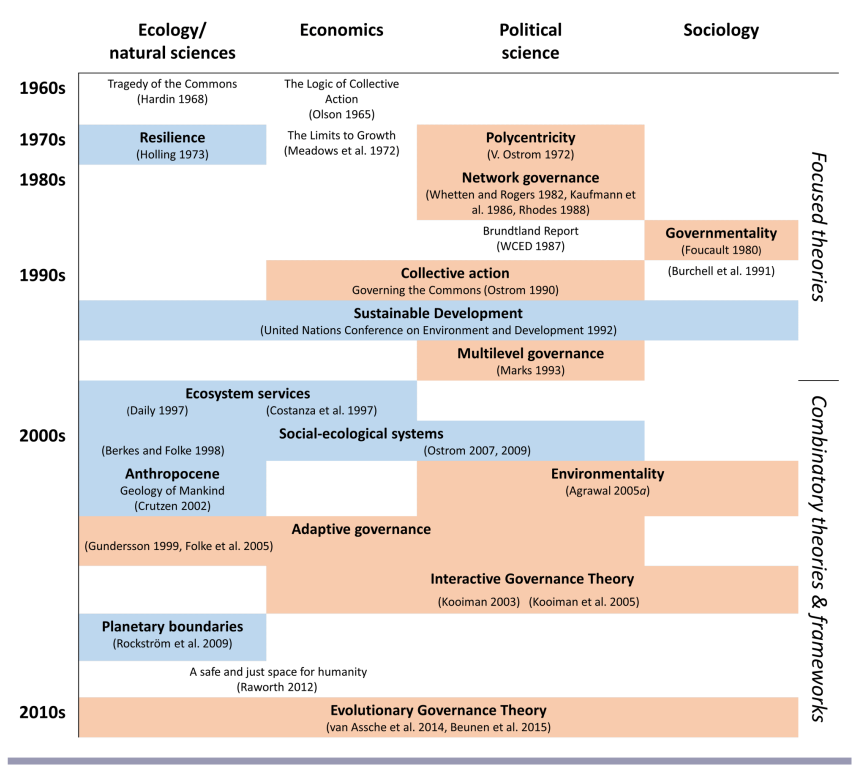

Focused theories

Out of the eight theories examined here, some can be characterized as specific in their focus but with more empirical support and literature behind them (Table 2). Polycentricity or network governance, for example, both examine the links or connections in governance processes. However, polycentricity emphasizes structural configurations of the governance system at a broader level, and network governance highlights agency and the flow of information within and between individuals or organizations. Both theories have literature integrating with multilevel perspectives, although formalization of multilevel governance theory followed later historically. Research questions where polycentricity theory is useful might include identifying where decisions are made for governance and by whom, and how the connections between these decision-making centers fit the context or shape outcomes. Network governance would be useful in examining questions related to information or resource flows between actors, and how the structure of actor networks influences governance processes and outcomes. Additionally, network governance is often used to examine patterns of coordination and collaboration within governance systems, which again highlights some similarities with the theory of polycentricity. 
Table 2. Focused theories. Their brief analytical strength and when they could be applied to coastal systems and beyond.

\begin{tabular}{|c|c|c|}
\hline Theory & Analytical strength & Applicable questions for coastal systems \\
\hline Polycentricity & $\begin{array}{l}\text { Linkages and decentralization of decision-making } \\
\text { processes. } \\
\text { Emphasizes structural configurations of the } \\
\text { governance system at a broader level. }\end{array}$ & $\begin{array}{l}\text { Where, and by whom, are decisions made influencing the coast? } \\
\text { Are connections between decision-making centers fit to the context of coastal } \\
\text { land-sea interactions with their diverse actors and uses? }\end{array}$ \\
\hline Network governance & $\begin{array}{l}\text { Connections in governance processes between } \\
\text { involved actors. } \\
\text { Highlights connectivity structures with emphasis } \\
\text { on agency and the flow of information within and } \\
\text { between actors. }\end{array}$ & $\begin{array}{l}\text { How does information flow between many diverse actors and use types? } \\
\text { How do coastal and terrestrial structures of actor networks influence } \\
\text { communication, governance processes, and outcomes? }\end{array}$ \\
\hline Collective action theory & $\begin{array}{l}\text { Community-based or local level, but also how } \\
\text { broader levels have influence locally, i.e., nested } \\
\text { governance via rules. } \\
\text { Focus on institutional structures and how those } \\
\text { shape actors' behavior. }\end{array}$ & $\begin{array}{l}\text { What variables influence whether local actors using shared coastal resources, i.e., } \\
\text { common property, are able to cooperate well or not? } \\
\text { Why is cooperation not working among diverse coastal actors, often with } \\
\text { divergent use types and interests? } \\
\text { Why are coastal resources becoming overexploited and quickly privatized? }\end{array}$ \\
\hline Governmentality/ & Socially constructed nature of governance. & What is the role of power, narratives, and discourse in marine governance \\
\hline Environmentality & $\begin{array}{l}\text { Relational dynamics between state governments, } \\
\text { governance institutions, and those being governed. }\end{array}$ & $\begin{array}{l}\text { agendas such as Blue Growth, the Blue Economy, and the UN Decade for Ocean } \\
\text { Science? } \\
\text { How are actions and subjectivities of individuals shaped or coerced into being } \\
\text { governed or not, particularly when defining new institutional spaces? }\end{array}$ \\
\hline $\begin{array}{l}\text { Multilevel governance } \\
\text { theory }\end{array}$ & $\begin{array}{l}\text { Governance integration processes across } \\
\text { administrative, legal, or institutional levels. }\end{array}$ & $\begin{array}{l}\text { How are higher level polices, e.g., international or national, transplanted, } \\
\text { transformed, or implemented, either administratively or in practice, into local } \\
\text { marine areas? Particularly policies with terrestrial governance origins, or in } \\
\text { shared marine regions such as the EU, South China Sea, the Arctic, or West } \\
\text { Africa involving multiple states in contested institutionally new areas. }\end{array}$ \\
\hline
\end{tabular}

For example, Morrison (2017) presents a 40-year analysis of Great Barrier Reef governance with polycentricity, revealing "how complex environmental regimes become increasingly structurally dense and eventually reach a point of stabilization" (p. E3013), emphasizing how polycentric structural configurations may be viewed as robust and complex, but that "stable structures can mask exogenous change, which then can generate more endogenous change" (p. E3013). Morrison et al. (2019) further brings a power perspective into polycentricity, proposing a framework to examine the role power plays in governance. Similarly, Van Leeuwen (2015) presents a historical analysis of shipping governance in the European Union, showing how "the emergence of regionally based loci of authority does mean that maritime governance is moving towards a more polycentric system" (p. 30). Van Leeuwen (2015) emphasizes the structural configuration of multiple organizations making interdependently influential decisions.

Whereas network governance also examines structure, numerous empirical analyses have highlighted the analytical strength of network governance as focusing on interactor learning, information sharing, communication strategies, and coordination as important (Newig et al. 2010, Pittman and Armitage 2017, Song et al. 2019b). Pittman and Armitage (2019), examining coastal governance processes in the Lesser Antilles, show that "actors and teams can exert significant steering influences over governance systems" (p. 68) and that "shifts in governance are occurring due to the strategies of autonomous actors" (p. 68). Polycentricity and network governance are complementary in their scope, but each contributes unique analytical richness.

Another distinction between theories is their focus within spatial, administrative, or institutional scales. Collective action theory has historically examined community-based or local level governance. Typical research questions for collective action theory would therefore focus on what variables and sets of rules influence whether local actors using a shared resource, i.e., common property, will cooperate successfully in governance or not. Ostrom's Governing the Commons (1990), demonstrates the local nature of self-organization processes, and the role that individual and group level variables play in shaping cooperative processes driving environmental commons outcomes. Later work, with the social-ecological systems framework (Ostrom 2009, McGinnis and Ostrom 2014) has shown how both social (e.g., leadership, gear type, local knowledge) and ecological variables (e.g., resource reproduction rates, size), at the local level, influence both social and environmental outcomes. Examples in the field of small scale fisheries would be Partelow et al. (2018a) and Chavez Carrillo et al. (2019).

In contrast, multilevel governance theory helps understand governance integration processes across administrative or legal aspects, as demonstrated in the case of Palau's marine conservation governance (Gruby and Basurto 2014) and EU (van Tatenhove 2015). Research questions for which multilevel governance theory would be useful might focus on how higher level policies, e.g., international or national, are transformed or implemented, either administratively or in practice, in regional or local areas (e.g., Song et al. 2019a). Similarly, Basurto (2013a) shows how multilevel governance theory is useful for unpacking national, regional, and local institutions for biodiversity conservation in Costa Rica. Findings indicate that multilevel linkages enhancing local autonomy are different from those that enable long-term stability. Basurto (2013b:582) also demonstrated that "configurations of institutional arrangements at different levels between actors or organizations can complement or conflict with each other." As noted, multilevel governance is helpful in the case of research questions of integration across social structural configurations, while collective action theory is strong in 
analyzing local level agent interactions within and between groups.

In general, the Ostroms had a substantial influence on environmental governance scholarship. They advanced collective action theory, polycentricity, and multilevel governance, and others not examined in this article including common property theory, institutional analysis, and social-ecological systems frameworks. There are certainly many other influential academics in the field we are not mentioning, and perhaps our author group is biased toward Ostrom scholarship given some of our backgrounds. Nonetheless, for those studying or researching environmental governance, their work is a part of its foundation.

The different strengths a theory has can also be differentiated according to its epistemological view on governance. Rooted in sociology, governmentality (along with environmentality) examines the socially constructed nature of governance. Song's (2015) analysis of South Korea's coastal governance near the disputed maritime border between North and South Korea shows the "hierarchical translation of power that facilitates governmentat-a-distance" (p. 68). Involving coastal fishing fleets, this happens discursively through government-imposed political narratives influencing fisher behavior in a way that helps to secure the coast against North Korea's intrusion, that is, by "using" fishers as civilian scouts who act to observe irregularities in the sea and report to the authority. Governmentality is thus useful for research questions that relate to power, narratives, and the influences between actors involved that make governance (im) possible. Governmentality has been applied extensively to examine the relationship between state governments and those being governed, e.g., individual actions, such as shown by Song (2015). Compared to the other focused theories, it takes a very different analytical and epistemological perspective that focuses on what shifts in the minds of agents to make them willing subjects. For example, governmentality differs from multilevel governance because it focuses on discursive and power relationships rather than legislative or administrative policy practices where multilevel governance is very useful in the European Union (EU) context, including environmental governance within the EU Common Fisheries Policy (Wilson 2009, van Hoof et al. 2012). Governmentality also differs substantially from collective action theory in how it views human behavior. Governmentality assumes that societal discourses are crucial to understand. Collective action theory is linked to bounded rationality, in that individuals tend to make rational choices based on self-interest, but within a context of incomplete information and institutional coercion toward group goals. Discourses are considered in collective action theory, in relation to mental models, but play a minor role (Denzau and North 1994, Ostrom 2007).

\section{Broader combinatory theories and frameworks}

In recent literature, more theories are being developed with a broader scope and capacity for analysis, perhaps given the adoption of systems thinking as an integral starting point, which can be seen as a way to integrate and combine the previously focused theories. In general, a divide between the focused and combinatory theories is a useful comparative frame because it reflects on how research has evolved from trying to understand a particular aspect of a system, e.g., how does collective action emerge, or on which level should an issue be governed, to a broader set of interacting social-ecological conditions, e.g., what are the drivers in this system, and how does it work as a whole. This shift is often, but not always, associated with normatively oriented concepts such as ecosystem services, social-ecological systems, resilience, and sustainability, e.g., sustainable development or the SDGs (Fig. 3).

If the aim is to gain a more comprehensive understanding of multiple factors influencing environmental governance, it quickly becomes clear that singular theoretical perspectives are not as well suited for the broader picture. Thus, what we refer to as a group of combinatory theories, i.e., broader theoretical frameworks, combining or building on multiple theoretical perspectives, can be identified as attempting a comprehensive and often pluralistic understanding. These have often emerged in tangent with, or become coupled with, the normative concepts mentioned above (Fig. 3). We believe using focused and combinatory as a comparative frame is useful, but that the distinction between focused hypotheses and broader analytical frameworks, at least terminologically, has become blurred.

Interactive governance theory (IGT), adaptive governance (AG), and EGT are combinatory theories (Table 3 ). Research questions within this sphere tend to broadly focus on how humanenvironment systems function interdependently, including the observable functionality and change processes of their governance over time and space (Cox and Schoon 2019). The term "complexity," although not often clearly defined, is often utilized in these analyses. For example, applications of adaptive governance have helped to identify elements leading to improved coastal outcomes (social and ecological). Schultz et al. (2015) note that governance processes, in their four cases, include the "negotiation and coordination between multiple ecosystem services and multiple interests across multiple levels and were adaptive, were learning-based, and developed with change" ( $\mathrm{p}$. 7373), and "will always involve a continuous learning process, nurturing of trust, reflection of procedures and structures, and developing collaboration toward common goals" (p. 7373). However, the most evident take away associated with adaptive governance is the inherent systems perspective. We can see here that broader theories and frameworks can help us understand the many present and interacting parts, but may struggle to identify detailed understandings of certain system features or facilitate comparison across systems, which shows the need for both focused and broader analyses (in methods, concepts, and theories) to work constructively in tangent.

Overall, IGT is the most problem-focused of the combinatory theories we considered, and it provides an analytical framework with fewer references to the fundamental theories described above. For example, Chuenpagdee (2011) provides examples of an IGT analysis in the realm of coastal conservation, arguing that "approaching governance with a holistic lens, like interactive governance and governability analysis, can help address concerns about sustainability," considering a "balance between ecological integrity and socio-economic viability" (p. 207). She also notes that conservation failures and conflict resulting from "resources decline, how some policies result in further devastation, and how scientific research offers argumentative findings instead of consensus," can be "systematically analyzed using [IGT]" (p. 
206-207). The broader system perspective is evident in its link to notions of sustainability.

Table 3. Combinatory theories and theoretical frameworks. Their brief analytical strength and when they could be applied to coastal systems and beyond.

\begin{tabular}{|c|c|c|}
\hline Theory & Analytical strength & $\begin{array}{l}\text { Applicable questions for coastal } \\
\text { systems }\end{array}$ \\
\hline $\begin{array}{l}\text { Adaptive } \\
\text { govern- } \\
\text { ance }\end{array}$ & $\begin{array}{l}\text { Iterative, learning-based, } \\
\text { inclusive processes of } \\
\text { governance. } \\
\text { Recognizes links } \\
\text { between ecological and } \\
\text { social processes across } \\
\text { levels and scales. }\end{array}$ & $\begin{array}{l}\text { How can collaborative governance be } \\
\text { established to facilitate sustainable } \\
\text { relationships between social and } \\
\text { environmental change, to make } \\
\text { coastal areas resilient to rising seas, } \\
\text { warming waters, increased storms, } \\
\text { intensive coastal developments, and } \\
\text { population density? }\end{array}$ \\
\hline $\begin{array}{l}\text { Interac- } \\
\text { tive } \\
\text { govern- } \\
\text { ance } \\
\text { theory }\end{array}$ & $\begin{array}{l}\text { Fit between governing } \\
\text { system and system being } \\
\text { governed. } \\
\text { What conditions make a } \\
\text { system more or less } \\
\text { governable? }\end{array}$ & $\begin{array}{l}\text { How can rapidly emerging and } \\
\text { changing coastal governance } \\
\text { institutions better fit their fluid and } \\
\text { rapidly changing context? } \\
\text { What are the unique coastal } \\
\text { conditions that make it more or less } \\
\text { difficult to govern? }\end{array}$ \\
\hline $\begin{array}{l}\text { Evoluti- } \\
\text { onary } \\
\text { govern- } \\
\text { ance } \\
\text { theory }\end{array}$ & $\begin{array}{l}\text { Change over time in } \\
\text { governance systems, } \\
\text { driven by multiple social } \\
\text { and material influences. } \\
\text { Discerning context- } \\
\text { specific options and } \\
\text { limits for intervention } \\
\text { and strategy. }\end{array}$ & $\begin{array}{l}\text { How is coastal governance evolving } \\
\text { and changing? Why? } \\
\text { What are all the different pieces } \\
\text { influencing coastal governance? } \\
\text { What are the current coastal } \\
\text { governance strategies and their } \\
\text { limitations? }\end{array}$ \\
\hline
\end{tabular}

Similarly, EGT combines various theoretical perspectives to encourage reflection on the complex processes of governance change. EGT is "evolutionary" by adding a strong temporal dimension to governance analysis, while taking a broad analytical view. For example, Schlüter et al. (2020a) use EGT to examine the diversity of coral reef governance challenges. The authors conclude "that EGT provides [its own] toolbox of very diverse and broad theories," and that marine systems "are a new sphere, where knowledge is relatively scarce and uncertainty is high," emphasizing "the role of discourse" in governance analysis among its other components. Although EGT adds numerous dimensions to environmental governance analysis, coevolution is the central feature. Coevolutions shape what is there and how it can be changed, e.g., toward more sustainable coastal governance. If unobserved, the limits of policy and planning are difficult to understand.

\section{Directions forward and beyond the coast}

We do not include all environmental governance theories or theoretical frameworks here. There are many more that have evolved or have been proposed at various stages of development (e.g., see Ansell and Torfing 2016, Cox et al. 2016, Nunan 2019). We encourage further reflection on what fundamental theories and assumptions are guiding environmental research and the analysis of policy practice, using coastal systems as an exemplary sector. We argue that when analysts know the analytical strengths of different theories, it will help create a toolbox of interdisciplinary analytical capacity within the field that its scholars are familiar with and thus able to better communicate about and work together on. However, a common toolbox is only helpful if we know the basics of how each theory can be used, and if those basics are generally understood and respected as valuable amongst other scholars. This synthesis aims to help facilitate this goal by synthesizing and highlighting the diverse analytical value of eight commonly used theories applied to the coastal realm. The strength and applicability of each theory will depend, as outlined above, on the particular research question and problem context of interest, whether coastal or beyond.

Understanding and using combinatory theoretical frameworks will require analysts with different skill sets, or more likely, multiple analysts from different conceptual, epistemological, and/or methodological backgrounds. A key conclusion of this article is that each theory has its own strength and value, and that by learning about this analytical diversity more comprehensively as a field, we can provide more constructive and cooperative scholarship. We can also observe that developing combinatory or integrated frameworks is a continuing trend, but that focused theories nonetheless remain crucial as building blocks for continued work. Focused and combinatory approaches have reciprocal and mutually beneficial goals. This suggests that there is a need for collaborative research, not only theoretically but in our methods and conceptual work to build theory, as a well-rounded effort mandates more "-arity" to advance environmental governance analysis. The notion of "-arity" includes multidisciplinarity (working in tangent with other disciplines), interdisciplinarity (integrated work with other disciplines), and transdisciplinarity (integrated work with nonacademics; Regeer and Bunders 2009). With a toolbox approach, "-arity" is not only necessary to simply understand the analyses of others, but also to broaden our own analytical capacity. Such progress is already evident within the coastal governance literature (Berkes 2015, Markus et al. 2018, Partelow et al. 2018c), and the broader environmental governance literature (Davidson and Frickel 2004, Campbell 2005, Bennett and Roth 2015, Cox et al. 2016, Bennett and Satterfield 2018, Colding and Barthel 2019). This emerging body of scholarship outlines the evolving nature and benefits of "-arity" and pursing collaborative scholarship in the environmental governance field.

We have used coastal systems as way to provide tangible context to our synthesis and comparison. However, we do believe the theories and lessons learned are applicable beyond coastal systems to other contexts in environmental governance. The foundational and synthesis literature of each theory is by no means limited to coastal analysis, and many governance challenges facing coastal systems occur elsewhere. Although context is increasingly recognized as an essential feature of environmental governance analysis, the nature of theories and theoretical frameworks is to bring out the core variables, principles, and relationships that may be generalizable. From this perspective we encourage reflection on the use and applicability of these theories beyond the coast, e.g., climate change, forestry, water management, grasslands, and urban areas, to consider which theories have been influential in steering governance thinking in those contexts and subfields, and how the evolution of theories and frameworks has led to the tools being used today.

${ }^{[1]}$ IGT possesses several slightly different strands, with Kooiman representing a more holistic, conceptual perspective characterized as "governance-as-networks" (Hill and Lynn 2015), or "socio- 
political governance" (Osborne 2011). Alternative perspectives are presented by Torfing et al. (2012) and Edelenbos and Meerkerk (2016).

Responses to this article can be read online at: http://www.ecologyandsociety.org/issues/responses. $\mathrm{php} / 12067$

\section{Acknowledgments:}

This research was conducted in the framework of European Cooperation in Science and Technology (COST) action on "Ocean Governance for Sustainability - challenges, options and the role of science" (CA15217). SP and ASc are thankful for general support from the Leibniz Centre for Tropical Marine Research (ZMT). LS acknowledges support from FCT/MCTES for the financial support to CESAM (UIDP/50017/2020+UIDB/50017/2020), through national funds. $N V$ partially acknowledges funding from the Romanian National Authority for Scientific Research and Innovation, CNCS-UEFISCDI PN-III-P1-1.1-TE-2016-2491, 2018.

\section{Data Availability:}

No data or code was used for this paper.

\section{LITERATURE CITED}

Abe, J., B. Brown, E. A. Ajao, and S. Donkor. 2016. Local to regional polycentric levels of governance of the Guinea Current Large Marine Ecosystem. Environmental Development 17:287-295. https://doi.org/10.1016/j.envdev.2015.06.006

Adger, W. N., T. P. Hughes, C. Folke, S. R. Carpenter, and J. Rockström. 2005. Social-ecological resilience to coastal disasters. Science 309(5737):1036-1039. https://doi.org/10.1126/science.1112122

Afroz, S., R. Cramb, and C. Grunbuhel. 2016. Collective management of water resources in Coastal Bangladesh: formal and substantive approaches. Human Ecology 44(1):17-31. https:// doi.org/10.1007/s10745-016-9809-x

Agrawal, A. 2001. Common property institutions and sustainable governance of resources. World Development 29(10):1649-1672. https://doi.org/10.1016/S0305-750X(01)00063-8

Agrawal, A. 2005a. Environmentality: technologies of government and the making of subjects. Duke University Press, Durham, North Carolina, USA.

Agrawal, A. 2005b. Environmentality: community, intimate government, and the making of environmental subjects in Kumaon, India. Current Anthropology 46(2):161-190. https://doi. org/10.1086/427122

Albert, M., and A. Vasilache. 2018. Governmentality of the Arctic as an international region. Cooperation and Conflict 53(1):3-22. https://doi.org/10.1177/0010836717703674

Alexander, S. M., M. Andrachuk, and D. Armitage. 2016. Navigating governance networks for community-based conservation. Frontiers in Ecology and the Environment 14:155-164. https://doi.org/10.1002/fee.1251

Aligica, P. D., and V. Tarko. 2012. Polycentricity: from Polanyi to Ostrom, and beyond. Governance 25(2):237-262. https://doi. org/10.1111/j.1468-0491.2011.01550.x

Álvarez-Romero, J. G., R. L. Pressey, N. C. Ban, and J. Brodie. 2015. Advancing land-sea conservation planning: integrating modelling of catchments, land-use change, and river plumes to prioritise catchment management and protection. PLOS ONE 10: e0145574. https://doi.org/10.1371/journal.pone.0145574

Andersson, K. P., and E. Ostrom. 2008. Analyzing decentralized resource regimes from a polycentric perspective. Policy Sciences 41:71-93. https://doi.org/10.1007/s11077-007-9055-6

Anh, P. T., S. R. Bush, A. P. J. Mol, and C. Kroeze. 2011. The multi-level environmental governance of Vietnamese aquaculture: global certification, national standards, local cooperatives. Journal of Environmental Policy and Planning 13(4):373-397. https://doi.org/10.1080/1523908X.2011.633701

Ansell, C., and J. Torfing, editors. 2016. Handbook on theories of governance. Edward Elgar, Cheltenham, UK. https://doi. org/10.4337/9781782548508

Armitage, D., and R. Plummer, editors. 2010. Adaptive capacity and environmental governance. Springer-Verlag, Berlin, Germany. https://doi.org/10.1007/978-3-642-12194-4

Armitage, D. R., R. Plummer, F. Berkes, R. I. Arthur, A. T. Charles, I. J. Davidson-Hunt, A. P. Diduck, N. C. Doubleday, D. S. Johnson, M. Marschke, P. McConney, E. W. Pinkerton, and E. K. Wollenberg. 2009. Adaptive co-management for socialecological complexity. Frontiers in Ecology and the Environment 7(2):95-102. https://doi.org/10.1890/070089

Ashlin, A. 2011. Adaptive governance and natural hazards: the 2004 Indian Ocean tsunami and the governance of coastal ecosystems in Sri Lanka. Pages 216-239 in E. Boyd and C. Folk, editors. Adapting institutions: governance, complexity and socialecological resilience. Cambridge University Press, Cambridge, UK. https://doi.org/10.1017/cbo9781139017237.015

Basurto, X. 2013a. Bureaucratic barriers limit local participatory governance in protected areas in Costa Rica. Conservation and Society 11(1):16-28. https://doi.org/10.4103/0972-4923.110942

Basurto, X. 2013b. Linking multi-level governance to local common-pool resource theory using fuzzy-set qualitative comparative analysis: insights from twenty years of biodiversity conservation in Costa Rica. Global Environmental Change 23 (3):573-587. https://doi.org/10.1016/j.gloenvcha.2013.02.011

Basurto, X., A. Bennett, A. Hudson Weaver, S. Rodriguez-Van Dyck, and J.-S. Aceves-Bueno. 2013. Cooperative and noncooperative strategies for small-scale fisheries' selfgovernance in the globalization era: implications for conservation. Ecology \& Society 18(4):38. https://doi. org/10.5751/ES-05673-180438

Basurto, X., E. Blanco, M. Nenadovic, and B. Vollan. 2016. Integrating simultaneous prosocial and antisocial behavior into theories of collective action. Science Advances 2(3):e1501220. https://doi.org/10.1126/sciadv.1501220 
Bavinck, M., R. Chuenpagde, M. Diallo, P. van der Heijden, J. Kooiman, R. Mahon, and S. Williams. 2005. Interactive fisheries governance: a guide to better practice. Eburon, Delft, The Netherlands.

Bavinck, M., R. Chuenpagdee, S. Jentoft, and J. Kooiman, editors. 2013. Governability of fisheries and aquaculture. MARE Publication Series 7. Springer, Dordrecht, The Netherlands. https://doi.org/10.1007/978-94-007-6107-0

Bennett, N. J., and R. Roth, editors. 2015. The conservation social sciences: What?, How? and Why? Canadian Wildlife Federation and Institute for Resources, Environment and Sustainability, University of British Columbia, Vancouver, British Columbia, Canada.

Bennett, N. J., and T. Satterfield. 2018. Environmental governance: a practical framework to guide design, evaluation, and analysis. Conservation Letters 11(6):e12600. https://doi. org/10.1111/conl.12600

Berkes, F. 2015. Coasts for people: interdisciplinary approaches to coastal and marine resource management. Routledge, New York, New York, USA. https://doi.org/10.4324/9781315771038

Berkes, F., J. Colding, and C. Folke. 2003. Navigating socialecological systems: building resilience for complexity and change. Cambridge University Press, Cambridge, UK. https://doi. org/10.1017/CBO9780511541957

Beunen, R., K. Van Assche, and M. Duineveld. 2015. Evolutionary governance theory: theory and applications. Springer, Cham, Switzerland. https://doi.org/10.1007/978-3-319-12274-8

Bevir, M. 2010. Rethinking governmentality: towards genealogies of governance. European Journal of Social Theory 13(4):423-441. https://doi.org/10.1177/1368431010382758

Binder, C. R., J. Hinkel, P. W. G. Bots, and C. Pahl-Wostl. 2013. Comparison of frameworks for analyzing social-ecological systems. Ecology and Society 18(4):26. https://doi.org/10.5751/ ES-05551-180426

Bodin, Ö. 2017. Collaborative environmental governance: achieving collective action in social-ecological systems. Science 357(6352):eaan1114. https://doi.org/10.1126/science.aan1114

Bodin, Ö., and B. I. Crona. 2009. The role of social networks in natural resource governance: What relational patterns make a difference? Global Environmental Change 19(3):366-374. https:// doi.org/10.1016/j.gloenvcha.2009.05.002

Brundtland, G. H. 1987. Our common future. The World Commission on Environment and Development. Oxford University Press, Oxford, UK

Burchell, G., C. Gordon, and P. Miller, editors. 1991. The Foucault effect: studies in governmentality. University of Chicago Press, Chicago, Illinois, USA. https://doi.org/10.7208/chicago/978022$\underline{6028811.001 .0001}$

Campbell, L. M. 2005. Diversity: overcoming obstacles to interdisciplinary research. Conservation Biology 19(2):574-577. https://doi.org/10.1111/j.1523-1739.2005.00058.x

Campbell, L. M., N. J. Gray, L. Fairbanks, J. J. Silver, R. L. Gruby, B. A. Dubik, and X. Basurto. 2016. Global oceans governance: new and emerging issues. Annual Review of Environment and Resources 41:517-543. https://doi.org/10.1146/annurevenviron-102014-021121

Carlisle, K., and R. L. Gruby. 2019. Polycentric systems of governance: a theoretical model for the commons. Policy Studies Journal 47(4):927-952. https://doi.org/10.1111/psj.12212

Carlisle, K. M., and R. L. Gruby. 2018. Why the path to polycentricity matters: evidence from fisheries governance in Palau. Environmental Policy and Governance 28(4):223-235. https://doi.org/10.1002/eet.1811

Cash, D. W., W. Adger, F. Berkes, P. Garden, L. Lebel, P. Olsson, L. Pritchard, and O. Young. 2006. Scale and cross-scale dynamics: governance and information in a multilevel world. Ecology and Society 11(2):8. https://doi.org/10.5751/ES-01759-110208

Chaffin, B. C., H. Gosnell, and B. A. Cosens. 2014. A decade of adaptive governance scholarship: synthesis and future directions. Ecology and Society 19(3):56. https://doi.org/10.5751/ES-06824-190356

Chaffin, B. C., and L. H. Gunderson. 2016. Emergence, institutionalization and renewal: rhythms of adaptive governance in complex social-ecological systems. Journal of Environmental Management 165:81-87. https://doi.org/10.1016/j.jenvman.2015.09.003

Chavez Carrillo, I. I., S. Partelow, R. Madrigal-Ballestero, A. Schlüter, and I. Gutierrez-Montes. 2019. Do responsible fishing areas work? Comparing collective action challenges in three small-scale fisheries in Costa Rica. International Journal of the Commons 13(1):705-746. https://doi.org/10.18352/ijc.923

Chen, S., and D. Ganapin. 2016. Polycentric coastal and ocean management in the Caribbean Sea Large Marine Ecosystem: harnessing community-based actions to implement regional frameworks. Environmental Development 17:264-276. https://doi. org/10.1016/j.envdev.2015.07.010

Chuenpagdee, R. 2011. Interactive governance for marine conservation: an illustration. Bulletin of Marine Science 87 (2):197-211. https://doi.org/10.5343/bms.2010.1061

Chuenpagdee, R., and S. Jentoft. 2015. Exploring challenges in small-scale fisheries governance. Pages 3-16 in S. Jentoft and R. Chuenpagdee, editors. Interactive governance for small-scale fisheries. MARE Publication Series 13. Springer, Cham, Switzerland. https://doi.org/10.1007/978-3-319-17034-3 1

Chuenpagdee, R., J. Kooiman, and R. Pullin. 2008. Assessing governability in capture fisheries, aquaculture and coastal zones. Journal of Transdisciplinary Environmental Studies 7(1):1-20.

Cinner, J. E., C. Folke, T. Daw, and C. C. Hicks. 2011. Responding to change: using scenarios to understand how socioeconomic factors may influence amplifying or dampening exploitation feedbacks among Tanzanian fishers. Global Environmental Change 21(1):7-12. https://doi.org/10.1016/j.gloenvcha.2010.09.001

Colding, J., and S. Barthel. 2019. Exploring the social-ecological systems discourse 20 years later. Ecology and Society 24(1):2. https://doi.org/10.5751/es-10598-240102

Costanza, R., R. d'Arge, R. de Groot, S. Farber, M. Grasso, B. Hannon, K. Limburg, S. Naeem, R. V. O'Neill, J. Paruelo, R. G. Raskin, P. Sutton, and M. van den Belt. 1997. The value of the 
world's ecosystem services and natural capital. Nature 387 (6630):253-260. https://doi.org/10.1038/387253a0

Cox, M., G. Arnold, and S. Villamayor Tomás. 2010. A review of design principles for community-based natural resource management. Ecology and Society 15(4):38. https://doi. org/10.5751/ES-03704-150438

Cox, M., and M. Schoon. 2019. Adaptive governance from an evolutionary perspective. Pages 78-93 in V. Galaz, editor. Global challenges, governance and complexity. Edward Elgar, Cheltenham, UK https://doi.org/10.4337/9781788115421.00014

Cox, M., S. Villamayor-Tomas, G. Epstein, L. Evans, N. C. Ban, F. Fleischman, M. Nenadovic, and G. Garcia-Lopez. 2016. Synthesizing theories of natural resource management and governance. Global Environmental Change 39:45-56. https://doi. org/10.1016/j.gloenvcha.2016.04.011

Crutzen, P. J. 2002. Geology of mankind. Nature 415(6867):23. https://doi.org/10.1038/415023a

Cvitanovic, C., A. J. Hobday, L. Van Kerkhoff, S. K. Wilson, K. Dobbs, and N. A. Marshall. 2015. Improving knowledge exchange among scientists and decision-makers to facilitate the adaptive governance of marine resources: a review of knowledge and research needs. Ocean \& Coastal Management 112:25-35. https://doi.org/10.1016/j.ocecoaman.2015.05.002

Daily, G. C., editor. 1997. Nature's services: societal dependence on natural ecosystems. Island, Washington, D.C., USA.

Darier, E. 1998. Foucault and the environment: an introduction. Pages 1-34 in E. Darier, editor. Discourses of the environment. Wiley-Blackwell, Hoboken, New Jersey, USA.

Davidson, D. J., and S. Frickel. 2004. Understanding environmental governance: a critical review. Organization and Environment 17(4):471-492. https://doi.org/10.1177/1086026603259086

Defeo, O., and J. C. Castilla. 2012. Governance and governability of coastal shellfisheries in Latin America and the Caribbean: multi-scale emerging models and effects of globalization and climate change. Current Opinion in Environmental Sustainability 4(3):344-350. https://doi.org/10.1016/j.cosust.2012.05.002

Denzau, A. T., and D. C. North. 1994. Shared mental models: idealogies and institutions. Kyklos 47(1):3-31. https://doi. org/10.1111/j.1467-6435.1994.tb02246.x

Dietz, T., E. Ostrom, and P. C. Stern. 2003. The struggle to govern the commons. Science 302(5652):1907-1912. https://doi. org/10.1126/science. 1091015

Duit, A., and V. Galaz. 2008. Governance and complexity emerging issues for governance theory. Governance 21(3):311-335. https://doi.org/10.1111/j.1468-0491.2008.00402.x

Duval-Diop, D., A. Senhoury, and P. Campredon. 2014. Governing through networks: working toward a sustainable management of West Africa's coastal mangrove ecosystems. Pages 191-206 in S. Diop, J.-P. Barusseau, and C. Descamps, editors. The landlocean interactions in the coastal zone of West and Central Africa. Springer, Cham, Switzerland. https://doi. org/10.1007/978-3-319-06388-1 16
Edelenbos, J., and I. van Meerkerk. 2016. Introduction: three reflecting perspectives on interactive governance. Pages 1-28 in J. Edelenbos and I. van Meerkerk, editors. Critical reflections on interactive governance: self-organization and participation in public governance. Edward Elgar, Cheltenham, UK. https://doi. org/10.4337/9781783479078.00006

Fletcher, R. 2010. Neoliberal environmentality: towards a poststructuralist political ecology of the conservation debate. Conservation and Society 8(3):171-181. https://doi. org/10.4103/0972-4923.73806

Fletcher, R. 2017. Geoforum environmentality unbound: multiple governmentalities in environmental politics. Geoforum 85:311-315. https://doi.org/10.1016/j.geoforum.2017.06.009

Fletcher, S., R. Jefferson, G. Glegg, L. Rodwell, and W. Dodds. 2014. England's evolving marine and coastal governance framework. Marine Policy 45:261-268. https://doi.org/10.1016/j. marpol.2013.09.007

Foley, P., and B. McCay. 2014. Certifying the commons: ecocertification, privatization, and collective action. Ecology and Society 19(2):28. https://doi.org/10.5751/ES-06459-190228

Folke, C., T. Hahn, P. Olsson, and J. Norberg. 2005. Adaptive governance of social-ecological systems. Annual Review of Environment and Resources 30(1):441-473. https://doi.org/10.1146/ annurev.energy.30.050504.144511

Foucault, M. 1980. Power/knowledge: selected interviews and other writings 1972-1977. C. Gordon, editor. Pantheon Books, New York, New York, USA.

Freire-Gibb, L. C., R. Koss, P. Margonski, and N. Papadopoulou. 2014. Governance strengths and weaknesses to implement the marine strategy framework directive in European waters. Marine Policy 44:172-178. https://doi.org/10.1016/j.marpol.2013.08.025

Galaz, V., B. Crona, H. Österblom, P. Olsson, and C. Folke. 2012. Polycentric systems and interacting planetary boundariesemerging governance of climate change-ocean acidificationmarine biodiversity. Ecological Economics 81:21-32. https://doi. org/10.1016/j.ecolecon.2011.11.012

Gallagher, A. 2010. The coastal sustainability standard: a management systems approach to ICZM. Ocean \& Coastal Management 53(7):336-349. https://doi.org/10.1016/j. ocecoaman.2010.04.017

Garmestani, A. S., and M. H. Benson. 2013. A framework for resilience-based governance of social-ecological systems. Ecology and Society 18(1):9. https://doi.org/10.5751/ES-05180-180109

Gelcich, S. 2014. Towards polycentric governance of small-scale fisheries: insights from the new 'management plans' policy in Chile. Aquatic Conservation: Marine and Freshwater Ecosystems 24(5):575-581. https://doi.org/10.1002/aqc.2506

Gelcich, S., T. P. Hughes, P. Olsson, C. Folke, O. Defeo, M. Fernández, S. Foale, L. H. Gunderson, C. Rodríguez-Sickert, M. Scheffer, R. S. Steneck, and J. C. Castilla. 2010. Navigating transformations in governance of Chilean marine coastal resources. Proceedings of the National Academy of Sciences 107 (39):16794-16799. https://doi.org/10.1073/pnas.1012021107 
Glaser, M., A. Breckwoldt, T. J. B. Carruthers, D. L. Forbes, S. Costanzo, H. Kelsey, R. Ramachandran, and S. Stead. 2018. Towards a framework to support coastal change governance in small islands. Environmental Conservation 45(3):227-237. https:// doi.org/10.1017/S0376892918000164

Glaser, M., and B. Glaeser. 2014. Towards a framework for crossscale and multi-level analysis of coastal and marine socialecological systems dynamics. Regional Environmental Change 14 (6):2039-2052. https://doi.org/10.1007/s10113-014-0637-5

Green, S. J., A. T. White, P. Christie, S. Kilarski, A. B. T. Meneses, G. Samonte-Tan, L. B. Karrer, H. Fox, S. Campbell, and J. D. Claussen. 2011. Emerging marine protected area networks in the coral triangle: lessons and way forward. Conservation and Society 9(3):173-188. https://doi.org/10.4103/0972-4923.86986

Gruby, R. L., and X. Basurto. 2014. Multi-level governance for large marine commons: politics and polycentricity in Palau's protected area network. Environmental Science and Policy 36:48-60. https://doi.org/10.1016/j.envsci.2013.08.001

Gunderson, L. 1999. Resilience, flexibility and adaptive management: antidotes for spurious certitude? Conservation Ecology 3(1):7. https://doi.org/10.5751/es-00089-030107

Gunderson, L. H., and C. S. Holling. 2002. Panarchy: understanding transformations in systems of humans and nature. Island, Washington, D.C., USA.

Gunderson, L., and S. S. Light. 2006. Adaptive management and adaptive governance in the Everglades ecosystem. Policy Sciences 39(4):323-334. https://doi.org/10.1007/s11077-006-9027-2

Gyau, A., S. Franzel, M. Chiatoh, G. Nimino, and K. Owusu. 2014. Collective action to improve market access for smallholder producers of agroforestry products: key lessons learned with insights from Cameroon's experience. Current Opinion in Environmental Sustainability 6(1):68-72. https://doi.org/10.1016/ j.cosust.2013.10.017

Hagan, A. M. O., and R. C. Ballinger. 2010. Implementing integrated coastal zone management in a national policy vacuum: local case studies from Ireland. Ocean \& Coastal Management 53 (12):750-759. https://doi.org/10.1016/j.ocecoaman.2010.10.014

Hanson, P. W. 2007. Governmentality, language ideology, and the production of needs in Malagasy conservation and development. Cultural Anthropology 22(2):244-284. https://doi.org/10.1525/ can.2007.22.2.244

Hardin, G. 1968. The tragedy of the commons. Science 162:1243-1248. https://doi.org/10.1126/science.162.3859.1243

Heikkila, T., S. Villamayor-Tomas, and D. Garrick. 2018. Bringing polycentric systems into focus for environmental governance. Environmental Policy and Governance 28(4):207-211. https://doi.org/10.1002/eet.1809

Hill, C. J., and L. E. Lynn. 2015. Public management: thinking and acting in three dimensions. Second edition. CQ Press, Washington, D.C., USA. https://doi.org/10.4135/9781483395814

Holahan, R., and M. Lubell. 2016. Collective action theory. Pages 21-31 in C. Ansell and J. Torfing, editors. Handbook on theories of governance. Edward Elgar, Cheltenham, UK. https://doi. org/10.4337/9781782548508.00010
Hughes, T. P., L. H. Gunderson, C. Folke, A. H. Baird, D. Bellwood, F. Berkes, B. Crona, A. Helfgott, H. Leslie, J. Norberg, M. Nyström, P. Olsson, H. Österblom, M. Scheffer, H. Schuttenberg, R. S. Steneck, M. Tengö, M. Troell, B. Walker, J. Wilson, and B. Worm. 2007. Adaptive management of the Great Barrier Reef and the Grand Canyon world heritage areas. Ambio 36(7):586-592. https://doi.org/10.1579/0044-7447(2007)36[586: AMOTGB]2.0.CO;2

Jentoft, S. 2007. Limits of governability: institutional implications for fisheries and coastal governance. Marine Policy 31(4):360-370. https://doi.org/10.1016/j.marpol.2006.11.003

Jentoft, S., and R. Chuenpagdee. 2009. Fisheries and coastal governance as a wicked problem. Marine Policy 33:553-560. https://doi.org/10.1016/j.marpol.2008.12.002

Jentoft, S., and R. Chuenpagdee. 2013. Concerns and problems in fisheries and aquaculture: exploring governability. Pages 33-44 in M. Bavinck, R. Chuenpagdee, S. Jentoft, and J. Kooiman, editors. Governability of fisheries and aquaculture. MARE Publication Series 7. Springer, Dordrecht, The Netherlands. https://doi.org/10.1007/978-94-007-6107-0 3

Jentoft, S., and R. Chuenpagdee, editors. 2015. Interactive governance for small-scale fisheries: global reflections. MARE Publication Series 13. Springer, Cham, Switzerland. https://doi. org/10.1007/978-3-319-17034-3

Jentoft, S., R. Chuenpagdee, M. J. Barragán-Paladines, and N. Franz. 2017. The small-scale fisheries guidelines: global implementation. MARE Publication Series 14. Springer, Cham, Switzerland. https://doi.org/10.1007/978-3-319-55074-9

Jentoft, S., T. C. Van Son, and M. Bjørkan. 2007. Marine protected areas: a governance system analysis. Human Ecology 35:611-622. https://doi.org/10.1007/s10745-007-9125-6

Jones, C., W. S. Hesterly, and S. P. Borgatti. 1997. A general theory of network governance: exchange conditions and social mechanisms. Academy of Management Review 22(4):911-945. https://doi.org/10.5465/amr.1997.9711022109

Kaufmann, F.-X., G. Majone, and V. Ostrom, editors. 1986. Guidance, control, and evaluation in the public sector: the Bielefeld Interdisciplinary Project. de Gruyter, Berlin, Germany.

Klijn, E.-H., and J. Koppenjan. 2012. Governance network theory: past, present and future. Policy and Politics 40(4):587-606. https://doi.org/10.1332/030557312X655431

Kooiman, J. 1993. Modern governance: new government-society interactions. Sage, London, UK.

Kooiman, J. 2003. Governing as governance. Sage, London, UK.

Kooiman, J. 2008. Exploring the concept of governability. Journal of Comparative Policy Analysis 10(2):171-190. https://doi. org/10.1080/13876980802028107

Kooiman, J. 2016. Interactive governance and governability. Pages 29-50 in J. Edelenbos and I. van Meerkerk, editors. Critical reflections on interactive governance: self-organization and participation in public governance. Edward Elgar, Cheltenham, UK. https://doi.org/10.4337/9781783479078.00007

Kooiman, J., M. Bavinck, R. Chuenpagdee, R. Mahon, and R. Pullin. 2008. Interactive governance and governability: an 
introduction. Journal of Transdisciplinary Environmental Studies $7(1): 1-11$.

Kooiman, J., S. Jentoft, R. Pullin, and M. Bavinck. 2005. Fish for life: interactive goverance for fisheries. MARE Publication Series 3. Amsterdam University Press, Amsterdam, The Netherlands. https://doi.org/10.1515/9789048505326

Koontz, T. M., D. Gupta, P. Mudliar, and P. Ranjan. 2015. Adaptive institutions in social-ecological systems governance: a synthesis framework. Environmental Science and Policy 53(Part B):139-151. https://doi.org/10.1016/j.envsci.2015.01.003

Kroon, F. J., and J. Brodie. 2009. Catchment management and health of coastal ecosystems: synthesis and future research. Marine and Freshwater Research 60(11):1196-1200. https://doi. org/10.1071/MF09228

Le Blanc, D., C. Freire, and M. Vierro. 2017. Mapping the linkages between oceans and other Sustainable Development Goals: a preliminary exploration. DESA Working Paper No. 149. United Nations Department of Economic and Social Affairs, New York, New York, USA. https://doi.org/10.18356/3adc8369-en

Lebel, L. 2012. Governance and coastal boundaries in the tropics. Current Opinion in Environmental Sustainability 4(2):243-251. https://doi.org/10.1016/j.cosust.2011.12.001

Lozano, A. J. G., and J. T. Heinen. 2016. Property relations and the co-management of small-scale fisheries in Costa Rica: lessons from marine areas for responsible fishing in the Gulf of Nicoya. Marine Policy 73:196-203. https://doi.org/10.1016/j.marpol.2016.08.011

Lubell, M. 2002. Environmental activism as collective action. Environment and Behavior 34(4):431-454. https://doi. org/10.1177/00116502034004002

Luke, T. W. 1998. Environmentality as green governmentality. Pages 121-151 in E. Darier, editor. Discourses of the environment. Wiley-Blackwell, Hoboken, New Jersey, USA.

Malette, S. 2009. Foucault for the next century: ecogovernmentality. Pages 221-239 in S. Binkley and J. CapetilloPonce, editors. A Foucault for the 21st century: governmentality, biopolitics and discipline in the new millennium. Cambridge Scholars, Newcastle upon Tyne, UK.

Marks, G. 1993. Structural policy and multi-level governance in the EC. Pages 391-411 in A. Cafruny and G. Rosenthal, editors. The state of the European Community: the Maastricht debates and beyond. Lynne Rienner, Boulder, Colorado, USA.

Markus, T., H. Hillebrand, A.-K. Hornidge, G. Krause, and A. Schlüter. 2018. Disciplinary diversity in marine sciences: the urgent case for an integration of research. ICES Journal of Marine Science 75(2):502-509. https://doi.org/10.1093/icesjms/fsx201

McGinnis, M. D. 2011. An introduction to IAD and the language of the Ostrom workshop: a simple guide to a complex framework. Policy Studies Journal 39(1):169-183. https://doi.org/10.1111/ j.1541-0072.2010.00401.x

McGinnis, M. D., and E. Ostrom. 2014. Social-ecological system framework: initial changes and continuing challenges. Ecology and Society 19(2):30. https://doi.org/10.5751/ES-06387-190230
McKenna, J., A. Cooper, and A. M. O'Hagan. 2008. Managing by principle: a critical analysis of the European principles of Integrated Coastal Zone Management (ICZM). Marine Policy 32:941-955. https://doi.org/10.1016/j.marpol.2008.02.005

Meadows, D. H., D. L. Meadows, J. Randers, and W. W. Behrens. 1972. The limits to growth. Potomac Associates, New York, USA. [online] URL: https://clubofrome.org/publication/the-limits-togrowth/

Meek, C. L., A. Lauren Lovecraft, R. Varjopuro, M. Dowsley, and A. T. Dale. 2011. Adaptive governance and the human dimensions of marine mammal management: implications for policy in a changing North. Marine Policy 35(4):466-476. https:// doi.org/10.1016/j.marpol.2010.10.021

Morrison, T. H. 2017. Evolving polycentric governance of the Great Barrier Reef. Proceedings of the National Academy of Sciences 114(15):E3013-E3021. https://doi.org/10.1073/pnas.1620830114

Morrison, T. H., W. N. Adger, K. Brown, M. C. Lemos, D. Huitema, J. Phelps, L. Evans, P. Cohen, A. M. Song, R. Turner, T. Quinn, and T. P. Hughes. 2019. The black box of power in polycentric environmental governance. Global Environmental Change 57:101934. https://doi.org/10.1016/j.gloenvcha.2019.101934

Neumann, B., A. T. Vafeidis, J. Zimmermann, and R. J. Nicholls. 2015. Future coastal population growth and exposure to sea-level rise and coastal flooding - a global assessment. PLOS ONE 10(3): e0118571. https://doi.org/10.1371/journal.pone.0118571

Newig, J., D. Günther, and C. Pahl-Wostl. 2010. Synapses in the network: learning in governance networks in the context of environmental management. Ecology and Society 15(4):24. https://doi.org/10.5751/ES-03713-150424

Ntona, M., and E. Morgera. 2018. Connecting SDG 14 with the other Sustainable Development Goals through marine spatial planning. Marine Policy 93:214-222. https://doi.org/10.1016/j. marpol.2017.06.020

Nunan, F. 2019. Governing renewable natural resources: theories and frameworks. First edition. Routledge, London, UK. https:// doi.org/10.4324/9780429053009

Olsen, S. B. 2003. Crafting coastal governance in a changing world. Coastal Resources Center, University of Rhode Island, Narragansett, Rhode Island, USA.

Olson, M. 1965. Logic of collective action: public goods and the theory of groups. Harvard University Press, Cambridge, Massachusetts, USA.

Olsson, P., C. Folke, and F. Berkes. 2004. Adaptive comanagement for building resilience in social-ecological systems. Environmental Management 34:75-90. https://doi.org/10.1007/s00267-003-0101-7

Osborne, S. P. 2011. Public governance and public services: a 'Brave New World' or new wine in old bottles? Chapter 29 in $\mathrm{T}$. Christensen and P. Lægreid, editors. The Ashgate Research Companion to new public management. Routledge, Abingdon, UK.

Österblom, H., and C. Folke. 2013. Emergence of global adaptive governance for stewardship of regional marine resources. Ecology and Society 18(2):4. https://doi.org/10.5751/ES-05373-180204 
Ostrom, E. 1990. Governing the commons: the evolution of institutions for collective action. Cambridge University Press, Cambridge, UK.

Ostrom, E. 1998. A behavioral approach to the rational choice theory of collective action. American Political Science Review 92 (1):1-22. https://doi.org/10.2307/2585925

Ostrom, E. 2007. A diagnostic approach for going beyond panaceas. Proceedings of the National Academy of Sciences 104 (39):15181-15187. https://doi.org/10.1073/pnas.0702288104

Ostrom, E. 2009. A general framework for analyzing sustainability of social-ecological systems. Science 325 (5939):419-422. https://doi.org/10.1126/science.1172133

Ostrom, E. 2010. Polycentric systems for coping with collective action and global environmental change. Global Environmental Change 20(4):550-557. https://doi.org/10.1016/j.gloenvcha.2010.07.004

Ostrom, E., and R. B. Parks. 1999. Neither Gargantua nor the Land of Lilliputs: conjectures on mixed systems of metropolitan organization. Pages 284-305 in M. D. McGinnis, editor. Polycentricity and local public economies: readings from the workshop in political theory and policy analysis. University of Michigan Press, Ann Arbor, Michigan, USA.

Ostrom, V. 1972. Polycentricity. Working Paper 2208. American Political Science Association, Washington, D.C., USA.

Ostrom, V., and E. Ostrom. 1991. Public goods and public choices: the emergence of public economies and industry structures. Pages 163-197 in V. Ostrom, editor. The meaning of American federalism: constituting a self-governing society. ICS, San Francisco, California, USA.

Ostrom, V., C. M. Tiebout, and R. Warren. 1961. The organization of government in metropolitan areas: a theoretical inquiry. American Political Science Review 55(4):831-842. https:// doi.org/10.1017/s0003055400125973

Partelow, S. 2018. A review of the social-ecological systems framework: applications, methods, modifications, and challenges. Ecology and Society 23(4):36. https://doi.org/10.5751/ES-10594-230436

Partelow, S., M. Glaser, S. Solano Arce, R. Sá Leitão Barboza, and A. Schlüter. 2018a. Mangroves, fishers, and the struggle for adaptive comanagement: applying the social-ecological systems framework to a marine extractive reserve (RESEX) in Brazil. Ecology and Society 23(3):19. https://doi.org/10.5751/es-10269-230319

Partelow, S., and K. Nelson. 2020. Social networks, collective action and the evolution of governance for sustainable tourism on the Gili Islands, Indonesia. Marine Policy 112. https://doi. org/10.1016/j.marpol.2018.08.004

Partelow, S., A. Schlüter, H. von Wehrden, M. Jänig, and P. Senff. 2018c. A sustainability agenda for tropical marine science. Conservation Letters 11(1):e12351. https://doi.org/10.1111/ conl.12351

Partelow, S., P. Senff, N. Buhari, and A. Schlüter. $2018 b$. Operationalizing the social-ecological systems framework in pond aquaculture. International Journal of the Commons 12 (1):485-518. https://doi.org/10.18352/ijc.834
Pierre, J., and B. G. Peters. 2005. Governing complex societies: trajectories and scenarios. Palgrave Macmillan, Basingstoke, UK. https://doi.org/10.1057/9780230512641

Pittman, J., and D. Armitage. 2016. Governance across the landsea interface: a systematic review. Environmental Science and Policy 64:9-17. https://doi.org/10.1016/j.envsci.2016.05.022

Pittman, J., and D. Armitage. 2017. How does network governance affect social-ecological fit across the land-sea interface? An empirical assessment from the Lesser Antilles. Ecology and Society 22(4):5. https://doi.org/10.5751/es-09593-220405

Pittman, J., and D. Armitage. 2019. Network governance of landsea social-ecological systems in the Lesser Antilles. Ecological Economics 157:61-70. https://doi.org/10.1016/j.ecolecon.2018.10.013

Polanyi, M. 1951. The logic of liberty. Routledge, London, UK. https://doi.org/10.4324/9781315006635

Portman, M. E., L. S. Esteves, X. Q. Le, and A. Z. Khan. 2012. Improving integration for integrated coastal zone management: an eight country study. Science of the Total Environment 439:194-201. https://doi.org/10.1016/j.scitotenv.2012.09.016

Poteete, A., M. A. Janssen, and E. Ostrom. 2010. Working together: collective action, the commons, and multiple methods in practice. Princeton University Press, Princeton, New Jersey, USA. https://doi.org/10.1515/9781400835157

Pulver, S., N. Ulibarri, K. L. Sobocinski, S. M. Alexander, M. L. Johnson, P. F. McCord, and J. Dell'Angelo. 2018. Frontiers in socio-environmental research: components, connections, scale, and context. Ecology and Society 23(3):23. https://doi. org/10.5751/ES-10280-230323

Radomski, P., and K. Van Assche. 2014. Lakeshore living: designing lake places and communities in the footprints of environmental writers. Michigan State University Press, East Lansing, Michigan, USA. ISBN: 9781611861181.

Raworth, K. 2012. A safe and just space for humanity: can we live within the doughnut? Oxfam International, Nairobi, Kenya. [online] URL: https://www.oxfam.org/en/research/safe-and-justspace-humanity

Rockström, J., W. Steffen, K. Noone, Å. Persson, F. S. Chapin, III, E. Lambin, T. M. Lenton, M. Scheffer, C. Folke, H. Schellnhuber, B. Nykvist, C. A. De Wit, T. Hughes, S. van der Leeuw, H. Rodhe, S. Sörlin, P. K. Snyder, R. Costanza, U. Svedin, M. Falkenmark, L. Karlberg, R. W. Corell, V. J. Fabry, J. Hansen, B. Walker, D. Liverman, K. Richardson, P. Crutzen, and J. Foley. 2009. Planetary boundaries: exploring the safe operating space for humanity. Ecology and Society 14(2):32. https://doi. org/10.5751/ES-03180-140232

Regeer, B. J., and J. F. G. Bunders. 2009. Knowledge co-creation: interaction between science and society. A transdisciplinary approach to complex societal issues. Number V.10e. Advisory Council for Spatial Planning, Nature and the Environment (RMMO), Den Haag, The Netherlands. ISBN 978-90-72377-79-1.

Rhodes, R. A. 1988. Beyond Westminster and Whitehall: the subcentral governments of Britain. Routledge, London, UK. 
Rijke, J., R. Brown, C. Zevenbergen, R. Ashley, M. Farrelly, P. Morison, and S. van Herk. 2012. Fit-for-purpose governance: a framework to make adaptive governance operational. Environmental Science and Policy 22:73-84. https://doi. org/10.1016/j.envsci.2012.06.010

Ringbom, H., and M. Joas. 2018. Introduction: multi-level regulation in the Baltic Sea region. Marine Policy 98:187-190. https://doi.org/10.1016/j.marpol.2018.09.017

Rittel, H. W., and M. M. Webber. 1974. Wicked problems. Manmade Futures 26(1):272-280.

Robins, G., L. Bates, and P. Pattison. 2011. Network governance and environmental management: conflict and cooperation. Public Administration 89(4):1293-1313. https://doi.org/10.1111/ j.1467-9299.2010.01884.x

Rochette, J., R. Billé, E. J. Molenaar, P. Drankier, and L. Chabason. 2015. Regional oceans governance mechanisms: a review. Marine Policy 60:9-19. https://doi.org/10.1016/j. marpol.2015.05.012

Rose, N., P. O'Malley, and M. Valverde. 2006. Governmentality. Annual Review of Law and Social Science 2:83-104. https://doi. org/10.1146/annurev.lawsocsci.2.081805.105900

Sabau, G. 2017. Costa Rica: a champion of the small-scale fisheries guidelines. Pages 355-378 in S. Jentoft, R. Chuenpagdee, M. J. Barragán-Paladines, and N. Franz, editors. The small-scale fisheries guidelines: global implementation. MARE Publication Series 14. Springer, Cham, Switzerland. https://doi. org/10.1007/978-3-319-55074-9_17

Santos, A. N., and C. Brannstrom. 2015. Livelihood strategies in a marine extractive reserve: implications for conservation interventions. Marine Policy 59:44-52. https://doi.org/10.1016/j. marpol.2015.05.004

Satizábal, P. 2018. The unintended consequences of 'responsible fishing' for small-scale fisheries: lessons from the Pacific coast of Colombia. Marine Policy 89:50-57. https://doi.org/10.1016/j. marpol.2017.12.005

Schlüter, A., S. Partelow, L. E. Torres-Guevara, and T. C. Jennerjahn. 2019. Coastal commons as social-ecological systems. Pages 170-187 in B. Hudson, J. Rosenbloom, and D. Cole, editors. Routledge handbook of the study of the commons. Routledge, London, UK. https://doi.org/10.4324/9781315162782-14

Schlüter, A., K. Van Assche, A. Hornidge, and N. Vãidianu. 2020b. Land-sea interactions and coastal development: an evolutionary governance perspective. Marine Policy 112:103801. https://doi.org/10.1016/j.marpol.2019.103801

Schlüter, A., C. Vance, and S. Ferse. 2020a. Coral reefs and the slow emergence of institutional structures for a glocal land- and sea-based collective dilemma. Marine Policy 112:103505. https:// doi.org/10.1016/j.marpol.2019.04.009

Schultz, L., C. Folke, H. Österblom, and P. Olsson. 2015. Adaptive governance, ecosystem management, and natural capital. Proceedings of the National Academy of Sciences 112 (24):7369-7374. https://doi.org/10.1073/pnas.1406493112
Scott, J. C. 1998. Seeing like a state: how certain schemes to improve the human condition have failed. Yale University Press, New Haven, Connecticut, USA. https://doi.org/10.2307/j.ctvxkn7ds

Seebens, H., M. T. Gastner, and B. Blasius. 2013. The risk of marine bioinvasion caused by global shipping. Ecology Letters 16(6):782-790. https://doi.org/10.1111/ele.12111

Sekhar, N. U. 2005. Integrated coastal zone management in Vietnam: present potentials and future challenges. Ocean \& Coastal Management 48(9-10):813-827. https://doi.org/10.1016/j. ocecoaman.2005.07.003

Song, A. M. 2015. Pawns, pirates or peacemakers: fishing boats in the inter-Korean maritime boundary dispute and ambivalent governmentality. Political Geography 48:60-71. https://doi. org/10.1016/j.polgeo.2015.06.002

Song, A. M., P. J. Cohen, Q. Hanich, T. H. Morrison, and N. Andrew. 2019a. Multi-scale policy diffusion and translation in Pacific Island coastal fisheries. Ocean \& Coastal Management 168:139-149. https://doi.org/10.1016/j.ocecoaman.2018.11.005

Song, A. M., J. P. Johnsen, and T. H. Morrison. 2018. Reconstructing governability: how fisheries are made governable. Fish and Fisheries 19(2):377-389. https://doi.org/10.1111/ $\underline{\text { faf. } 12262}$

Song, A. M., O. Temby, D. Kim, A. Saavedra Cisneros, and G. M. Hickey. 2019b. Measuring, mapping and quantifying the effects of trust and informal communication on transboundary collaboration in the Great Lakes fisheries policy network. Global Environmental Change 54:6-18. https://doi.org/10.1016/j. gloenvcha.2018.11.001

Spalding, M. J. 2016. The new blue economy: the future of sustainability. Journal of Ocean and Coastal Economics 2(2):8. https://doi.org/10.15351/2373-8456.1052

Steinberg, P. E. 2013. Of other seas: metaphors and materialities in maritime regions. Atlantic Studies 10(2):156-169. https://doi. org/10.1080/14788810.2013.785192

Stephenson, P. 2013. Twenty years of multi-level governance: 'Where does it come from? What is it? Where is it going?' Journal of European Public Policy 20(6):817-837. https://doi. org/10.1080/13501763.2013.781818

Thatcher, M. 1998. The development of policy network analysis: from modest origins to overarching frameworks. Journal of Theoretical Politics 10(4):389-416. https://doi.org/10.1177/0951$\underline{692898010004002}$

Torfing, J., B. G. Peters, J. Pierre, and E. Sørensen. 2012. Interactive governance: advancing the paradigm. Oxford University Press, Oxford, UK.

Tuda, A. O., S. Kark, and A. Newton. 2019. Exploring the prospects for adaptive governance in marine transboundary conservation in East Africa. Marine Policy 104:75-84. https://doi. org/10.1016/j.marpol.2019.02.051

UNESCO Intergovernmental Oceanographic Commission (UNESCO-IOC). 2017. Global ocean science report: the current status of ocean science around the world. UNESCO, Paris. 
United Nations. 1992. United Nations Conference on Environment and Development. UN, Rio de Janeiro, Brazil, 3-14 June. https:// www.un.org/en/conferences/environment/rio1992

United Nations. 2010. Transforming our world: the 2030 agenda for sustainable development. UN, New York, New York, USA.

United Nations. 2016. UN Atlas of the Oceans. UN, New York, New York, USA.

United Nations Environment Programme(UNEP). 2020. Coastal zone management. UNEP, Nairobi, Kenya. [online] URL: https:// www.unenvironment.org/explore-topics/oceans-seas/what-we-do/ working-regional-seas/coastal-zone-management

Van Assche, K., R. Beunen, and M. Duineveld. 2014. Evolutionary governance theory. Springer, Cham, Switzerland. https://doi. org/10.1007/978-3-319-00984-1

Van Assche, K., R. Beunen, M. Duineveld, and M. Gruezmacher. 2017. Power/knowledge and natural resource management: Foucaultian foundations in the analysis of adaptive governance. Journal of Environmental Policy and Planning 19(3):308-322. https://doi.org/10.1080/1523908X.2017.1338560

Van Assche, K., R. Beunen, M. Gruezmacher, R. Beunen, and M. Gruezmacher. 2020b. Rethinking strategy in environmental governance. Journal of Environmental Policy \& Planning 22 (5):695-708. https://doi.org/10.1080/1523908X.2020.1768834

Van Assche, K., and A.-K. Hornidge. 2015. Rural development: knowledge and expertise in governance. Wageningen Academic, Wageningen, The Netherlands. https://doi.org/10.3920/978-90-8686-812-4

Van Assche, K., A.-K. Hornidge, A. Schlüter, and N. Vaidianu. $2020 \mathrm{a}$. Governance and the coastal condition: towards new modes of observation, adaptation and integration. Marine Policy 112. https://doi.org/10.1016/j.marpol.2019.01.002

van den Eeden, P., and H. J. Hüttner. 1982. A short history of multi-level research. Current Sociology 30(3):9-25. https://doi. org/10.1177/001139282030003004

van Hoof, L., J. van Leeuwen, and J. van Tatenhove. 2012. All at sea; regionalisation and integration of marine policy in Europe. Maritime Studies 11:9. https://doi.org/10.1186/2212-9790-11-9

van Leeuwen, J. 2015. The regionalization of maritime governance: towards a polycentric governance system for sustainable shipping in the European Union. Ocean \& Coastal Management 117:23-31. https://doi.org/10.1016/j.ocecoaman.2015.05.013

van Tatenhove, J. P. M. 2015. Marine governance: institutional capacity-building in a multi-level governance setting. Pages 35-52 in M. Gilek and K. Kern, editors. Governing Europe's marine environment: Europeanization of regional seas or regionalization of EU policies? Ashgate, Farnham, UK.

van Tatenhove, J. P. M. 2017. Transboundary marine spatial planning: a reflexive marine governance experiment? Journal of Environmental Policy \& Planning 19(6):783-794. https://doi. org/10.1080/1523908x.2017.1292120

Vince, J. 2014. Oceans governance and marine spatial planning in Australia. Australian Journal of Maritime \& Ocean Affairs 6 (1):5-17. https://doi.org/10.1080/18366503.2014.888137
Visbeck, M. 2018. Ocean science research is key for a sustainable future. Nature Communications 9:690. https://doi.org/10.1038/ $\underline{\text { s41467-018-03158-3 }}$

Wedding, L. M., S. M. Reiter, C. R. Smith, K. M. Gjerde, J. N. Kittinger, A. M. Friedlander, S. D. Gaines, M. R. Clark, A. M. Thurnherr, S. M. Hardy, and L. B. Crowder. 2015. Managing mining of the deep seabed. Science 349(6244):144-145. https:// doi.org/10.1126/science.aac6647

Whetten, D. A., and D. L. Rogers. 1982. Interorganizational coordination: theory, research, and implementation. Iowa State University Press, Ames, Iowa, USA.

Wilson, D. C. 2009. The paradoxes of transparency: science and the ecosystem approach to fisheries management in Europe. MARE Publication Series 5. Amsterdam University Press, Amsterdam, The Netherlands.

World Bank. 2020. Understanding poverty: blue economy. World Bank, Washington, D.C., USA. [online] URL:https://www. worldbank.org/en/topic/oceans-fisheries-and-coastal-economies

Wright, G. 2015. Marine governance in an industrialised ocean: a case study of the emerging marine renewable energy industry. Marine Policy 52:77-84. https://doi.org/10.1016/j.marpol.2014.10.021 